\title{
Seasonal and interannual variations in the nitrogen cycle in the Arabian Sea
}

\author{
T. Rixen ${ }^{1,2}$, A. Baum ${ }^{1}$, B. Gaye ${ }^{2}$, and B. Nagel $^{3}$ \\ ${ }^{1}$ Leibniz Center for Tropical Marine Ecology, Fahrenheitstr. 6, 28359 Bremen, Germany \\ ${ }^{2}$ Institute of Marine Biogeochemistry and Marine Chemistry, University of Hamburg, Bundestsr. 55, \\ 20148 Hamburg, Germany \\ ${ }^{3}$ Helmholtz Centre Geesthacht, Institute of Coastal Research, Max-Planck-Straße 1, 21502 Geesthacht, Germany \\ Correspondence to: T. Rixen (tim.rixen@zmt-bremen.de)
}

Received: 22 August 2013 - Published in Biogeosciences Discuss.: 13 December 2013

Revised: 2 September 2014 - Accepted: 11 September 2014 - Published: 16 October 2014

\begin{abstract}
The Arabian Sea plays an important role in the marine nitrogen cycle because of its pronounced mid-water oxygen minimum zone (OMZ) in which bio-available nitrate $\left(\mathrm{NO}_{3}^{-}\right)$is reduced to dinitrogen gas $\left(\mathrm{N}_{2}\right)$. As the nitrogen cycle can respond fast to climate-induced changes in productivity and circulation, the Arabian Sea sediments are an important palaeoclimatic archive. In order to understand seasonal and interannual variations in the nitrogen cycle, nutrient data were obtained from the literature published prior to 1993, evaluated, and compared with data measured during five expeditions carried out in the framework of the Joint Global Ocean Flux Study (JGOFS) in the Arabian Sea in 1995 and during a research cruise of RV Meteor in 2007. The data comparison showed that the area characterized by a pronounced secondary nitrite maximum (SNM) was by $63 \%$ larger in 1995 than a similarly determined estimate based on pre-JGOFS data. This area, referred to as the core of the denitrifying zone, showed strong seasonal and interannual variations driven by the monsoon. During the SW monsoon, the SNM retreated eastward due to the inflow of oxygenenriched Indian Ocean Central Water (ICW). During the NE monsoon, the SNM expanded westward because of the reversal of the current regime. On an interannual timescale, a weaker SW monsoon decreased the inflow of ICW from the equatorial Indian Ocean and increased the accumulation of denitrification tracers by extending the residence time of water in the SNM. This is supported by palaeoclimatic studies showing an enhanced preservation of accumulative denitrification tracers in marine sediments in conjunction with a weakening of the SW monsoon during the late Holocene.
\end{abstract}

\section{Introduction}

The marine nitrogen cycle, which strongly influences the fertility of the ocean and the sequestration of $\mathrm{CO}_{2}$ from the atmosphere, is mainly controlled by nitrogen fixation $\left(\mathrm{N}_{2} \rightarrow \mathrm{NH}_{3}\right)$ and the reduction of $\mathrm{NO}_{3}^{-}$to dinitrogen gas $\left(\mathrm{NO}_{3}^{-} \rightarrow \mathrm{N}_{2}\right.$; Brandes and Devol, 2002; Deutsch et al., 2007; Dugdale and Goering, 1967; McElroy, 1983). The reduction of $\mathrm{NO}_{3}^{-} \rightarrow \mathrm{N}_{2}$, referred to as denitrification (Eqs. 1-3), is a combination of different microbial processes such as the $\mathrm{NO}_{3}^{-}$(Eq. 1) and $\mathrm{NO}_{2}^{-}$reduction (Eq. 2), which can be expressed stoichiometrically as follows:

(1) nitrate reduction:

$$
\begin{aligned}
& \left(\mathrm{CH}_{2} \mathrm{O}\right)_{106}\left(\mathrm{NH}_{3}\right)_{16}\left(\mathrm{H}_{3} \mathrm{PO}_{4}\right)+260 \mathrm{HNO}_{3} \\
& \rightarrow 106 \mathrm{CO}_{2}+276 \mathrm{HNO}_{2}+\mathrm{H}_{3} \mathrm{PO}_{4}+122 \mathrm{H}_{2} \mathrm{O}
\end{aligned}
$$

(2) nitrite reduction:

$$
\begin{aligned}
& 1.75\left(\mathrm{CH}_{2} \mathrm{O}\right)_{106}\left(\mathrm{NH}_{3}\right)_{16}\left(\mathrm{H}_{3} \mathrm{PO}_{4}\right)+276 \mathrm{HNO}_{2} \\
& \rightarrow 185.16 \mathrm{CO}_{2}+150.23 \mathrm{~N}_{2}+1.75 \mathrm{~N}_{2} \mathrm{O} \\
& +1.75 \mathrm{H}_{3} \mathrm{PO}_{4}+365.1 \mathrm{H}_{2} \mathrm{O} \\
& (1+2) \text { denitrification: } \\
& 2.75\left(\mathrm{CH}_{2} \mathrm{O}\right)_{106}\left(\mathrm{NH}_{3}\right)_{16}\left(\mathrm{H}_{3} \mathrm{PO}_{4}\right)+260 \mathrm{HNO}_{3} \\
& \rightarrow 291.17 \mathrm{CO}_{2}+150.23 \mathrm{~N}_{2}+1.75 \mathrm{~N}_{2} \mathrm{O} \\
& +2.75 \mathrm{H}_{3} \mathrm{PO}_{4}+487.1 \mathrm{H}_{2} \mathrm{O} .
\end{aligned}
$$

Approximately $30 \%$ of the global oceanic water-column denitrification occurs in the oxygen minimum zone (OMZ) 
of the central and eastern Arabian Sea (Bange et al., 2000; Bulow et al., 2010; Codispoti et al., 2001a; Devol et al., 2006; Naqvi, 1987; Nicholls et al., 2007; Ward et al., 2009). In the western Arabian Sea on the highly productive Oman shelf, the co-occurrence of denitrification, the dissimilatory $\mathrm{NO}_{2}^{-}$reduction (DNRA), and anaerobic ammonium oxidation (anammox) were assumed to be the pathways through which $\mathrm{NO}_{3}^{-}$was reduced to $\mathrm{N}_{2}$ (Jensen et al., 2011).

Nitrogen budgets of the Arabian Sea show that today $\mathrm{NO}_{3}^{-}$ losses from the OMZ are mainly balanced by inputs of $\mathrm{NO}_{3}^{-}$ through the northward propagating Indian Ocean Central Water (ICW; Bange et al., 2000). As documented in the sedimentary record, this ventilation has fluctuated at millennial timescales in the Pleistocene and determined the position and extent of the OMZ and denitrification (Pichevin et al., 2007). In order to study recent changes of the nitrogen cycle in the Arabian Sea, we evaluated and compared nutrient data obtained from the literature published prior to 1993 (Naqvi and Shailaja, 1993; Naqvi, 1991) during five expeditions carried out within the framework of US Joint Global Ocean Flux Study (JGOFS) in 1995 (Morrison et al., 1998) and a research cruise of RV Meteor in 2007 (M74/1b; Fig. 1). The results were furthermore compared to sedimentary records from the Arabian Sea covering the last 11700 years (Altabet et al., 2002; Pichevin et al., 2007).

\section{Study area}

The Arabian Sea is strongly influenced by the Asian monsoon, which is driven by summer heating and winter cooling of the Asian land mass (Ramage, 1987). Winter cooling increases productivity and organic carbon export by deepening the mixed layer and thereby entraining nutrients into the euphotic zone (Rixen et al., 2005, 2009; Wiggert et al., 2000, 2002). In summer (SW monsoon), the strong heating forms an atmospheric low over Asia that attracts the SE trade winds of the Southern Hemisphere. After crossing the Equator, the SE winds turn to SW winds forming a low-level, crossequatorial jet stream, which is indicated by enhanced wind speeds over the Arabian Sea (Fig. 1; Findlater, 1977). This so-called Findlater Jet causes upwelling off Somalia, Yemen, and Oman, which is the main process controlling biological productivity and the associated export of organic matter from the sunlit surface ocean into the deep sea during the SW monsoon (Brock et al., 1991, 1992; Rixen et al., 2000, 2009). Contrary to expectations, the OMZ is spatially separated from the highly productive zones in the western and northern Arabian Sea and is most pronounced in the northeastern Arabian Sea (Naqvi, 1991). This spatial separation is caused by the oceanographic conditions characterized by a strong propagation of ICW via the Somali Current through the Strait of Socotra into the western Arabian Sea (Fischer et al., 1996b; Stramma et al., 1996). The ICW originates by convective mixing in the southern Indian Ocean (Sverdrup

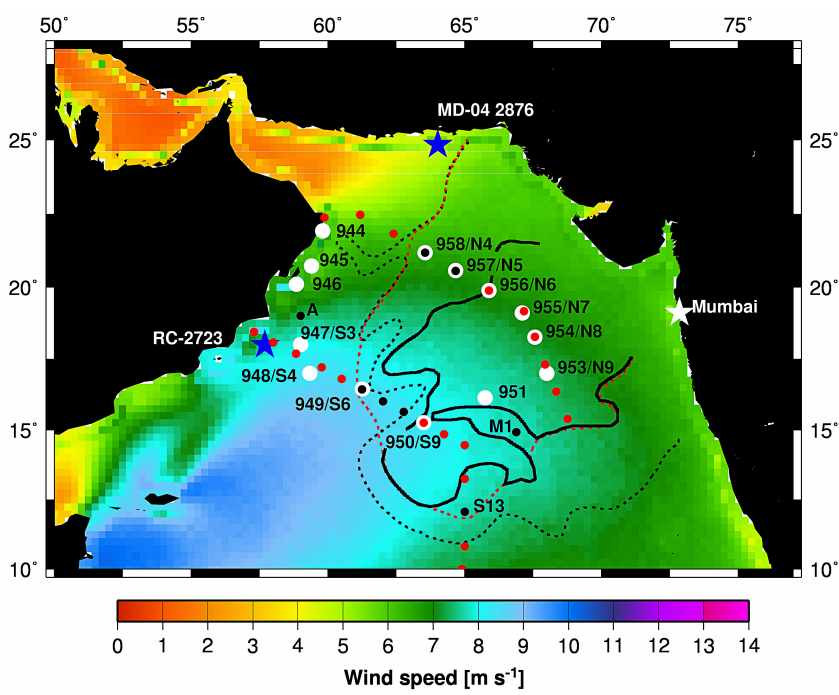

Figure 1. Mean SW monsoon winds speeds over the Arabian Sea. The area of enhanced wind speeds indicates the Findlater Jet. The black lines were redrawn from Naqvi and Shailaja (1996) and show the expansion of the area in which $\mathrm{NO}_{2}^{-}$concentrations within the SNM were $>0.5 \mu \mathrm{mol} \mathrm{kg}^{-1}$ (broken line) and $>2 \mu \mathrm{mol} \mathrm{kg}-1$ (solid line). Circles represent the stations covered during the US JGOFS expeditions in 1995 (red and black) and the RV Meteor cruise M74/1b in 2007 (white). The M74 stations are indicated by the numbers 944-958 and the US JGOFS station numbers are A, M1, S(1-13), and N(1-11). The station at which nitrite concentrations $>2 \mu \mathrm{mol} \mathrm{kg}{ }^{-1}$ were observed outside the area marked by Naqvi and Shailaja (1996) in 1995 are indicated by the black circles. Based on these stations and the former $0.5 \mu \mathrm{mol} \mathrm{kg}{ }^{-1}$ line, the expansion of the area in which $\mathrm{NO}_{2}^{-}$concentrations within the SNM were $>2 \mu \mathrm{mol} \mathrm{kg}^{-1}$ in 1995 was drawn (red broken line). The blue stars indicate the location of the sediment cores MD-04 2876 (Pichevin et al., 2007) and RC-2723 (Altabet et al., 2002).

et al., 1942) and mixes with the Indonesian Throughflow and Subtropical Subsurface Water (SSW) prior to its entry into the Arabian Sea (Schott and McCreary, 2001). Overall the ICW contributes approximately $25 \%$ to the thermocline waters in the upper OMZ (water depth $<500$ ) of the Arabian Sea (Rixen and Ittekkot, 2005). In addition to the ICW, Red Sea and Arabian Sea High Salinity Water also contribute to the formation of the thermocline water referred to as the North Indian High Salinity Intermediate Water (NIHSIW; Morrison et al., 1998; Schott and McCreary, 2001; You, 1997). During winter, the prevailing NE winds (NE monsoon) reverse the surface ocean circulation in the Arabian Sea and the Somali Current (Fischer et al., 1996a; Schott and McCreary, 2001).

\section{Methods}

During the RV Meteor cruise M74/1b from 18 September to 4 October 2007 in the Arabian Sea, water samples for 


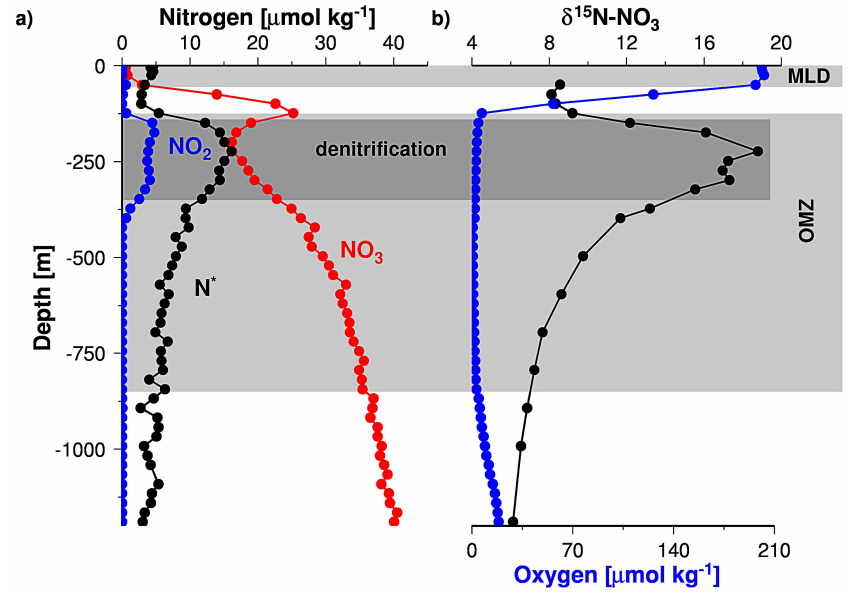

Figure 2. (a) Vertical profiles of nitrite, $\mathrm{NO}_{3}^{-}$and $\mathrm{N}^{*}$ and (b) of oxygen and $\mathrm{d}^{15} \mathrm{~N}$ of $\mathrm{NO}_{3}^{-}$and nitrite $\left(\mathrm{d}^{15} \mathrm{~N}_{\mathrm{NO}_{3}}\right)$ at station 953 (see Fig. 1 for location).

the determination of nutrients $\left(\mathrm{NO}_{3}^{-}, \mathrm{NO}_{2}^{-}, \mathrm{PO}_{4}^{3-}\right)$ were obtained from a General Oceanics rosette water sampler equipped with 18 sample bottles. Out of the total 14 stations, $5(949,950,953,955$, and 957) were sampled with a high vertical resolution $(25 \mathrm{~m})$ down to a water depth of $1200 \mathrm{~m}$ (Figs. 1, 2). The rosette water sampler was attached to a Sea-Bird CTD, which was additionally equipped with a fluorescence and an oxygen sensor (SBE 43). In addition to the SBE43, a microsensor and, at a selected depth, a STOX (Switchable Trace amount OXygen) sensor were also used by Jensen et al. (2011). The STOX sensor revealed a detection limit of $90 \mathrm{nmol} \mathrm{O}_{2} \mathrm{~L}^{-1}$ during the in situ deployments. The STOX data were used to calibrate the microsensor, and the calibrated microsensor data correlate with SBE43 data. However, at oxygen concentrations $<0.4 \mu \mathrm{M}$, SBE43 remained constant, showing that lower oxygen concentrations could not be resolved. The Winkler method was used to calibrate the SBE43 data, and the resulting regression equation $(y=1.03 \times)$ was forced to the zero intercept.

Nutrients were analysed on board with a SKALAR autoanalyser according to the methods described by Grasshoff et al. (1999). Grasshoff et al. (1999) and US JGOFS programme (Morrison et al., 1999) followed the standard procedure for the determination of $\mathrm{NO}_{2}^{-}$as introduced by Bendschneider and Robinson (1952). After reducing $\mathrm{NO}_{3}^{-}$to $\mathrm{NO}_{2}^{-}$by using a copperized cadmium column, $\mathrm{NO}_{2}^{-}$was analysed using the same method. To quantify $\mathrm{NO}_{3}^{-}$deficits, we used the tracer $N^{*}\left(N *=\left(\left[\mathrm{NO}_{3}^{-}\right]-16 \times\left[\mathrm{PO}_{4}^{3-}\right]+2.9\right) \times 0.87\right)$, according to which $\mathrm{NO}_{3}^{-}$deficits are represented as negative values (Gruber and Sarmiento, 1997). In order to avoid negative values, we multiplied $N^{*}$ by -1 . Accordingly, increasing $\mathrm{NO}_{3}^{-}$ deficits are expressed as increasing positive $N^{*}$ values.

$\delta^{15} \mathrm{~N}$ of $\mathrm{NO}_{3}^{-}\left(\delta^{15} \mathrm{~N}_{\mathrm{NO}_{3}}\right)$ was determined using the "denitrifier method" developed by Sigman et al. (2001). Results are reported in per mill using the delta notation:

$$
\begin{aligned}
& \delta^{15} \mathrm{~N}_{\text {sample }}=\left(\left({ }^{15} \mathrm{~N} /{ }^{14} \mathrm{~N}\right)_{\text {sample }} /\left({ }^{15} \mathrm{~N} /{ }^{14} \mathrm{~N}\right)_{\text {reference }}-1\right) \\
& \times 1000,
\end{aligned}
$$

with air $\mathrm{N}_{2}$ being the reference for ${ }^{15} \mathrm{~N} /{ }^{14} \mathrm{~N}$. Pseudomonas chlororaphis (ATCC\#13985, formerly known as Pseudomonas aureofaciens) was used to transform $\mathrm{NO}_{3}^{-}$and $\mathrm{NO}_{2}^{-}$ to $\mathrm{N}_{2} \mathrm{O}$, which is subsequently analysed for its nitrogen isotope values using a Delta Plus XP mass spectrometer. Isotope values were calibrated using IAEA-N3 and USGS-34 with assigned $\delta^{15} \mathrm{~N}$ values of +4.7 and $-1.8 \%$ (Böhlke et al., 2003). An internal $\mathrm{KNO}_{3}$ standard was used for further quality assurance. Nitrogen isotope values were corrected using a single-point correction referring to IAEA-N3. Since $\mathrm{NO}_{2}^{-}$was not removed from the OMZ samples prior to isotope analysis, and since chlororaphis used for the "denitrifier method" converts $\mathrm{NO}_{3}^{-}$and $\mathrm{NO}_{2}^{-}$to $\mathrm{N}_{2} \mathrm{O}, \delta^{15} \mathrm{~N}_{\mathrm{NO}_{3}}$ values from 125 to $400 \mathrm{~m}$ water depth have to be considered combined $\mathrm{N}$ isotope values for $\mathrm{NO}_{3}^{-}$and $\mathrm{NO}_{2}^{-}$. $\mathrm{N}$ isotope values of pure $\mathrm{NO}_{3}^{-}$from these water depths are higher than their $\mathrm{N}$ isotope values from mixed $\mathrm{NO}_{3}^{-}$plus $\mathrm{NO}_{2}^{-}$, because $\mathrm{NO}_{2}^{-} \mathrm{N}$ isotope values from OMZs are negative (Casciotti and McIlvin, 2007; Gaye et al., 2013). The standard deviation for IAEA-N3 was $0.3 \%$, which is in the same range for $\delta^{15} \mathrm{~N}_{\mathrm{NO}_{3}}$ for at least duplicate measurements of the samples.

\section{Results and discussion}

\subsection{The secondary nitrite maximum (SNM)}

In the central and eastern Arabian Sea, increased $\mathrm{NO}_{2}^{-}$concentrations occurred within the upper part of the OMZ corresponding to oxygen concentrations $<5 \mu \mathrm{M}$ (Fig. 2). This $\mathrm{NO}_{2}^{-}$accumulation was first reported in 1933/1934 (Gilson, 1937) and is referred to as the secondary nitrite maximum (SNM). $\mathrm{NO}_{2}^{-}$is an intermediate product, formed during nitrification and $\mathrm{NO}_{3}^{-}$reduction (see Eqs. 1-3). Due to the lack of oxygen required for nitrification, the formation of the SNM was assumed to be caused primarily by denitrification (Naqvi, 1991). This view was furthermore supported by nutrient profiles showing that the SNM was associated with a pronounced $\mathrm{NO}_{3}^{-}$deficit. As mentioned before, this deficit can be calculated as $N^{*}$ (Gruber and Sarmiento, 1997). The highest $\mathrm{NO}_{3}^{-}$deficit coincided with a pronounced positive deviation of the $\delta^{15} \mathrm{~N}$ values of $\mathrm{NO}_{3}^{-}$, which was observed by Naqvi et al. (1998) and Naqvi (1991) as well as during our cruise in 2007 (Fig. 2). The enrichment of the heavier isotope ${ }^{15} \mathrm{~N}$ in $\mathrm{NO}_{3}^{-}$is caused by the isotopic fractionation during $\mathrm{NO}_{3}^{-}$reduction, in the course of which the lighter isotope ${ }^{14} \mathrm{~N}$ is preferentially transformed into $\mathrm{NO}_{2}^{-}$(Cline and Kaplan, 1975; Mariotti et al., 1981). However, Bulow et al. (2010) found that $\mathrm{NO}_{2}^{-}$concentrations increase in conjunction with rising denitrification rates. Consequently, $\mathrm{NO}_{2}^{-}$ 
concentrations close to zero indicate very low denitrification rates, implying that denitrification was mainly restricted to the SNM in the upper part of the OMZ during the cruises (Fig. 2).

Recently developed ${ }^{15} \mathrm{~N}$ incubation experiments indicated that other processes could also produce and consume $\mathrm{NO}_{2}^{-}$, such as $\mathrm{NO}_{3}^{-}$reduction decoupled from denitrification, $\mathrm{NH}_{4}^{+}$ oxidation, $\mathrm{NO}_{2}^{-}$oxidation, and anammox (Jensen et al., 2011; Lam et al., 2011). According to these experiments the $\mathrm{NO}_{3}^{-}$reduction rate had a maximum of $29.7 \mathrm{nmol} \mathrm{L}^{-1}$ day ${ }^{-1}$ and the $\mathrm{NO}_{2}^{-}$oxidation rates reached values of up to $22 \mathrm{nmol} \mathrm{L}^{-1} \mathrm{day}^{-1}$. These two processes were considered the main sources and sinks, respectively, of $\mathrm{NO}_{2}^{-}$in the SNM. $\mathrm{NH}_{4}^{+}$oxidation (up to $3.6 \mathrm{nmol} \mathrm{L}^{-1} \mathrm{day}^{-1}$ ) and $\mathrm{NO}_{2}^{-}$reduction by anammox (up to $2-4 \mathrm{nmol} \mathrm{NL}^{-1}$ day $^{-1}$ ) were a minor source and sink. Integrated over the water column, these sources slightly exceeded the sinks, suggesting a net $\mathrm{NO}_{2}$ production of $0.06 \mathrm{mmol} \mathrm{N} \mathrm{m}^{-2}$ day $^{-1}$. Due to this low net production, the $\mathrm{NO}_{2}^{-}$mass balance calculations indicated a mean residence time of 49 years of water within the OMZ. Such a long residence time, in addition to high anammox rates (up to $39 \mathrm{nmol} \mathrm{N} \mathrm{L}^{-1}$ day $^{-1}$ ) measured along the Oman shelf, leads to the conclusion that processes at the basin's boundaries were mainly responsible for the severe $\mathrm{NO}_{3}^{-}$deficits seen in the SNM of the whole Arabian Sea (Lam et al., 2011). The residence time of nitrite-enriched OMZ waters resulting from these rate measurements of 49 years is within the upper range of earlier estimates, which vary between 1 and 50 years (Naqvi and Shailaja, 1993; Olson et al., 1993; Sen Gupta and Naqvi, 1984). The only study using trichlorofluoromethane for calculating the residence time suggested a mean residence time of 10 years for waters in the OMZ (Olson et al., 1993). Such a residence time is too short to explain the occurrence of the SNM by just considering $\mathrm{NO}_{3}^{-}$reduction, $\mathrm{NH}_{4}^{+}$oxidation, $\mathrm{NO}_{2}^{-}$oxidation, and anammox, and consequently calls for additional $\mathrm{NO}_{2}^{-}$ sources.

Low anammox rates $\left(<4.23 \mathrm{nmol} \mathrm{NL}^{-1}\right.$ days $\left.^{-1}\right)$ in the central Arabian Sea have also been confirmed in other experiments (Bulow et al., 2010; Nicholls et al., 2007; Ward et al., 2009). However, in contrast to Jensen et al. (2011) and Lam et al. (2011), these studies obtained substantially higher denitrification rates, with averages between $8.45( \pm 2.78)$ and $9.1( \pm 1) \mathrm{nmol} \mathrm{L}^{-1} \mathrm{day}^{-1}$ (Bulow et al., 2010; Devol et al., 2006; Ward et al., 2009). Such rates suggest, in conjunction with an area of active denitrification of $1.37 \times 10^{12} \mathrm{~m}^{2}$ (Naqvi, 1991) and a vertical extension of the SNM of $250 \mathrm{~m}$ (Fig. 2), a $\mathrm{NO}_{3}^{-}$loss rate ranging from 0.71 to $1.40 \times 10^{12} \mathrm{~mol} \mathrm{~N} \mathrm{yr}^{-1}\left(\sim 9.9-19.7 \mathrm{Tg} \mathrm{N} \mathrm{yr}^{-1}\right)$. The resulting average $\mathrm{NO}_{3}^{-}$loss of $15.4 \pm 4.3 \mathrm{Tg} \mathrm{Nyr}^{-1}$ is within the medium range of previously published denitrification rates ranging from approximately 2 to $4 \mathrm{Tg} \mathrm{N} \mathrm{yr}^{-1}$ (Deuser et al., 1978; Naqvi et al., 1982; Somasundar et al., 1990) to values of 10 and $30 \mathrm{Tg} \mathrm{N} \mathrm{yr}^{-1}$ (e.g. Bange et al., 2000; Gaye et al., 2013; Howell et al., 1997) and even reaching values of $60 \mathrm{Tg} \mathrm{Nyr}^{-1}\left(4.28 \times 10^{12} \mathrm{~mol} \mathrm{~N} \mathrm{yr}^{-1}\right)$. While the lower estimates were mainly derived from $\mathrm{NO}_{3}^{-}$losses obtained and interpolated through different methods and nitrogen isotopic mass balance calculations, the high rate of $60 \mathrm{Tg} \mathrm{N} \mathrm{yr}^{-1}$ was based on the excess $\mathrm{N}_{2}$ concentrations derived from $\mathrm{N}_{2} / \mathrm{Ar}$ ratios (Codispoti, 2007; Codispoti et al., 2001b). However, this comparison indicates that, considering the uncertainties, the denitrification rate measured by Devol et al. (2006) and Bulow et al. (2010) could explain $\mathrm{NO}_{3}^{-}$deficits in the $\mathrm{OMZ}$ of the Arabian Sea. The formation of $\mathrm{NO}_{2}^{-}$during denitrification (Bulow et al., 2010) could furthermore be the additional $\mathrm{NO}_{2}^{-}$source required to explain the lower residence times of water in the OMZ. This, in addition to low anammox rates in the SNM, supports the original assumption of Naqvi (1991), who used the occurrence of the SNM to map the spatial extent of the denitrifying zone.

\subsection{Spatial expansion of the SNM}

For mapping the spatial extent of the SNM, data from approximately 674 stations north of $10^{\circ} \mathrm{N}$ were available in 1991 (Naqvi, 1991). These data included also those which were obtained almost 50 years ago during the International Indian Ocean Expeditions (IIOE). Stations with SNM $>2 \mu \mathrm{mol} \mathrm{kg}{ }^{-1}$ were considered to be part of the core denitrifying zone. The resulting map (see Fig. 1) indicates the maximum expansion of the core of the denitrifying zone prior to 1991. However, uneven data coverage in space and time was assumed to bias the mapped extent of the denitrifying zone (Naqvi, 1991). The main problems were that the data density was higher during the NE monsoon than during the SW monsoon and that more data were collected in the northwestern Arabian Sea than in the remaining parts.

To reduce problems associated with the spatial coverage, all data were collected along a pre-defined station grid during the five US JGOFS cruises in 1995 (Figs. 1, 3). The five data sets revealed a pronounced seasonality of the denitrification zone, with the least expansion during the early phase of the SW monsoon (Figs. 3, 4; Codispoti, 2000; Morrison et al., 1998). During the NE monsoon, the denitrification zone expanded westward. However, in 1995 an SNM was observed at stations (e.g. N4, S6 and S13) where no SNM was observed prior to 1991 (Fig. 1). In the northern and western Arabian Sea, it seems that the area which was characterized by $\mathrm{NO}_{2}^{-}$concentrations between 0.5 and $2 \mu \mathrm{mol} \mathrm{kg}-1$ prior to 1991 revealed $\mathrm{NO}_{2}^{-}$concentration $>2 \mu \mathrm{mol} \mathrm{kg}^{-1}$ in 1995 (see red broken line in Fig. 1). This represents an expansion of the area known to be characterized by $\mathrm{NO}_{2}^{-}$concentration $>2 \mu \mathrm{mol} \mathrm{kg}^{-1}$ by $63 \%$ from 0.56 to $0.91 \times 10^{12} \mathrm{~m}^{2}$. In view of the data limitation and the fact that these stations in the north and west were characterized by an SNM with $\mathrm{NO}_{2}^{-}$concentrations $>0.5 \mu \mathrm{mol} \mathrm{kg}-1$ even prior to 1991 , we would not call it a trend but rather an indication of considerable seasonal and interannual variation in denitrification. 

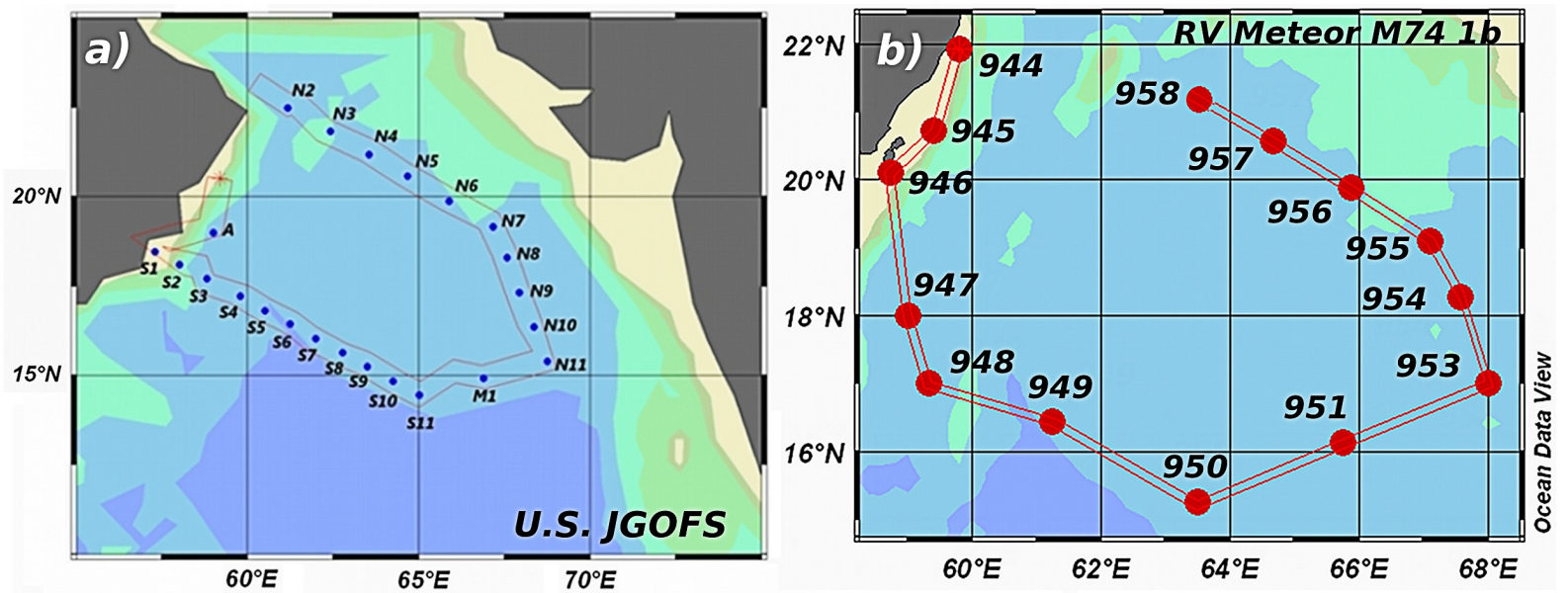

\section{U.S. JGOFS}

\section{RV Meteor M74 $1 b$}
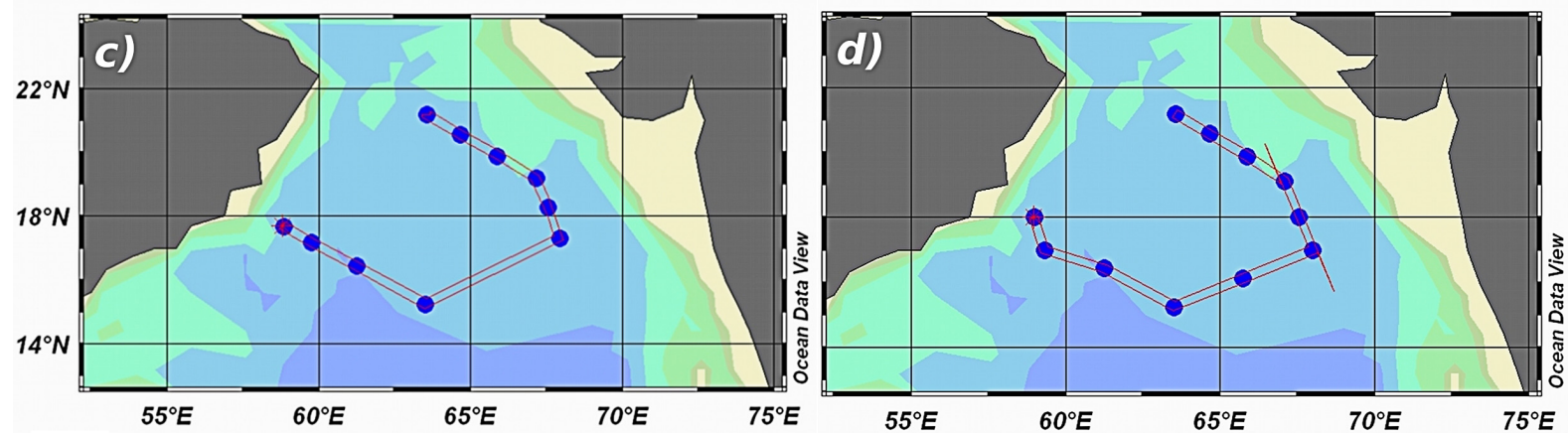

Figure 3. Cruise tracks and stations of the US JGOFS cruises in 1995 (a) and the RV Meteor cruise M74/1b in 2007 (b), as well as the transects used to produce the cross sections in Fig. 4 (a), Fig. 5 (b), and Fig. 6 (c, d).

\subsection{Seasonal variability in the SNM}

In order to study processes controlling the seasonal variability of denitrification, we compared the stations within the SNM in the eastern and northeastern part of the Arabian Sea with the western stations which were in the upwelling area and had no pronounced SNM (Fig. 4). All nutrient data, oxygen concentrations, and densities of water masses within the SNM were averaged (Table 1). The obtained data show a negative correlation between mean oxygen concentrations and the mean $\mathrm{NO}_{3}^{-}$deficit, expressed as $N^{*}$, indicating that decreasing oxygen concentrations favoured denitrification in the SNM (Fig. 5a). The correlation between oxygen concentrations and $N^{*}$ (which was not found at the western stations) confirms that denitrification was significant below an oxygen concentration of approximately $1 \mu \mathrm{M}$. Since denitrification does not utilize oxygen, the decreasing oxygen concentrations associated with increasing $N^{*}$ indicates that denitrification was also coupled to processes using up oxygen such as nitrite oxidation and/or aerobic respiration (Gaye et al., 2013).

In 1995 the lowest mean oxygen concentrations in the SNM occurred during the peak of the SW monsoon (August/September; Fig. 5b), when the enhanced supply of or- ganic matter reduced oxygen concentrations and induced denitrification as reflected in high $N^{*}$ values (Table 1, Fig. 5a). The second pronounced drop of oxygen occurred between November and December, when the organic carbon flux was relatively low (Fig. 5b). This decrease could have been associated with a reversing current regime, in the course of which the westward flowing water lead to the westward expansion of the SNM (Fig. 4, cruise ttn53). After the spring reversal of the current regime around March/April, the oxygen concentrations in the SNM continued to rise (Fig. 5b) and the SNM retreated eastward between the late NE monsoon and the early SW monsoon (Fig. 4).

\subsection{The role of the shelf and slope}

The Indian shelf has low oxygen concentrations, especially during and after the SW monsoon (Naqvi et al., 2000), and denitrification rates measured during this time north of $14.5^{\circ} \mathrm{N}$ at water depth between 20 and $80 \mathrm{~m}$ reveal a mean denitrification rate of $52.7 \mathrm{nmol} \mathrm{N} \mathrm{L}^{-1}$ day $^{-1}$ (Devol et al., 2006). This rate is approximately 6 times higher than denitrification rates within the SNM and even exceeds the high anammox rates on the Oman continental margin (Devol et al., 2006; Jensen et al., 2011). In order to estimate 


\section{SW monsoon}

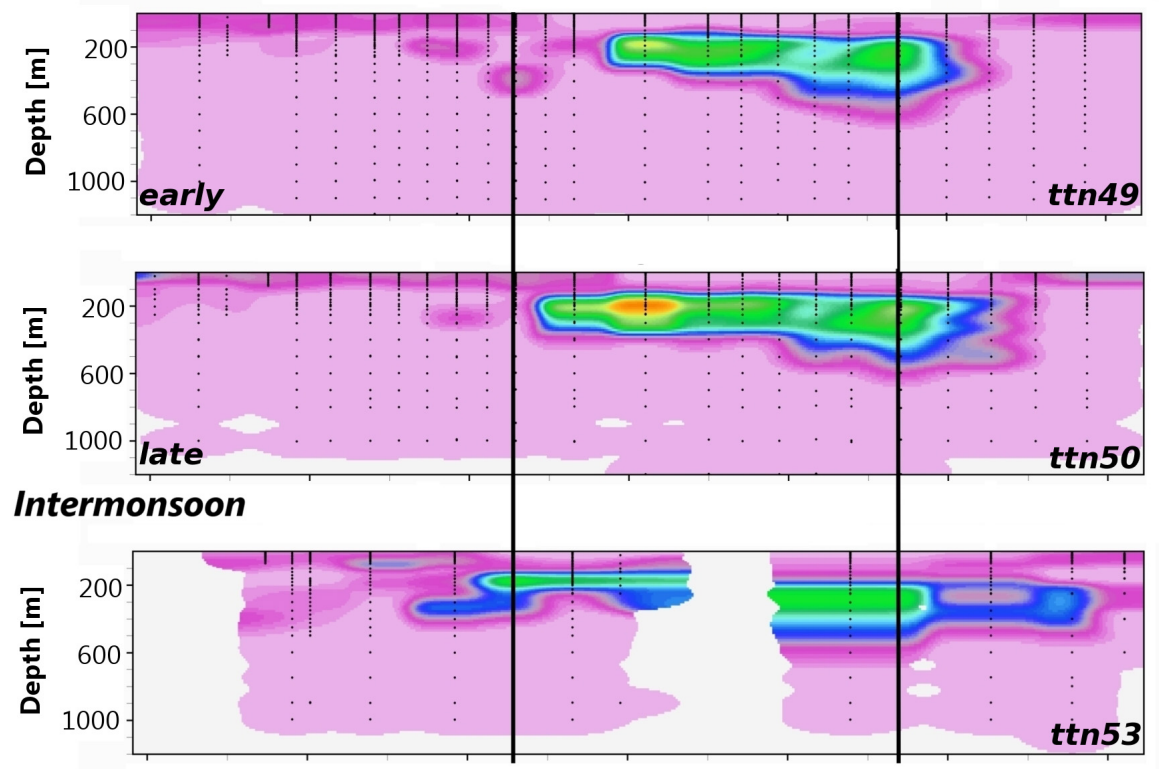

NE monsoon

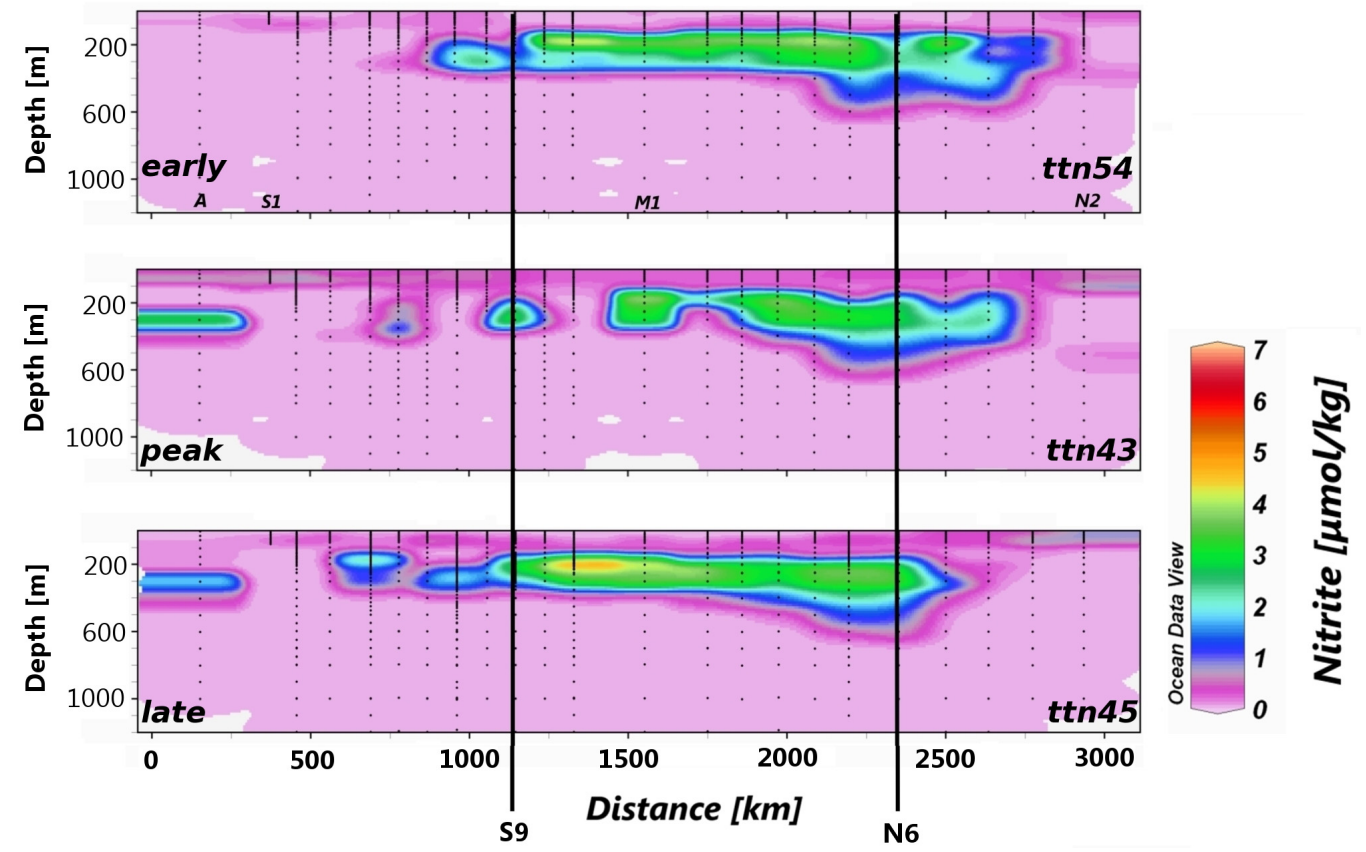

Figure 4. Cross sections showing the seasonal nitrite concentrations along the JGOFS transects from the Oman coast (station A, S1) towards the central and eastern Arabian Sea (stations M1) and the northern part of the eastern Arabian Sea (M1 - N2; compare Fig. 3a, Table 1). The vertical black line shows the maximum expansion of the core of the denitrifying zone in 1993.

the $\mathrm{NO}_{3}^{-}$loss in the water column on the shelf, the "1-arcminute global relief model" (ETOPO01; Amante and Eakins, 2009) was used to calculate the volume of water within the depth range of $20-100 \mathrm{~m}$ on the Indian shelf between 14.5 and $22^{\circ} \mathrm{N}$. The resulting volume of $6.47 \times 10^{12} \mathrm{~m}^{3}$ and the mean denitrification rate of $52.7 \mathrm{nmol} \mathrm{N}^{-1}$ day $^{-1}$ suggest a mean $\mathrm{NO}_{3}^{-}$loss of $1.74 \mathrm{Tg} \mathrm{Nyr}^{-1}$. The assumption that denitrification occurs only during and after the SW monsoon between June and October results in a more conservative estimate of $0.73 \mathrm{Tg} \mathrm{N} \mathrm{yr}^{-1}$. The sedimentary denitrification on the Indian shelf was estimated to be $1.3 \mathrm{Tg} \mathrm{N} \mathrm{yr}^{-1}$ (Naik, 2006), and thus the total $\mathrm{NO}_{3}^{-}$loss on the shelf was between 2 and $3 \mathrm{Tg} \mathrm{Nyr}^{-1}$. This represents approximately 13 to $20 \%$ of the previously estimated $\mathrm{NO}_{3}^{-}$loss rate of $15.36 \mathrm{Tg} \mathrm{N} \mathrm{yr}^{-1}$ within the SNM. The SNM in the open ocean is spatially 
Table 1. Cruises, dates, phases of the monsoon, nutrient and oxygen concentrations, temperatures, salinities, and sigma-t, averaged for the core of the denitrifying zone SNM indicated by $\mathrm{NO}_{2}^{-}$concentrations $>2 \mu \mathrm{mol} \mathrm{kg}^{-1}$ at oxygen concentrations $<5 \mu \mathrm{mol} \mathrm{kg}-1$ and within almost the same density range in the western Arabian Sea west of $62.5^{\circ}$ E. Only samples for which both $\mathrm{NO}_{3}^{-}$and $\mathrm{PO}_{4}^{3-}$ were measured were considered.

\begin{tabular}{llllrrrrrrr}
\hline Cruise & Date & $\begin{array}{l}\text { Phases of the } \\
\text { monsoon }\end{array}$ & $\mathrm{NO}_{2}^{-}$ & $N^{*}$ & $\begin{array}{r}\mathrm{PO}_{4}^{3-} \\
\mu \mathrm{mol} \mathrm{kg}^{-1}\end{array}$ & $\mathrm{NO}_{3}^{-}$ & $\mathrm{O}_{2}$ & $\begin{array}{r}\text { Temp. } \\
{ }^{\circ} \mathrm{C}\end{array}$ & Salinity & Sigma-t \\
\hline SNM & & & & & & & & & & \\
Ttn49 & 18 Jul-13 Aug 1995 & SW - early & 3.11 & 14.56 & 2.48 & 19.98 & 0.92 & 15.77 & 35.86 & 26.48 \\
Ttn50 & 14 Aug-13 Sep 1995 & SW - late & 3.19 & 15.29 & 2.53 & 19.98 & 0.72 & 17.06 & 35.89 & 26.30 \\
M74 & 18 Sep-4 Oct 2007 & SW - late & 3.80 & 14.45 & 2.40 & 18.94 & 1.43 & 15.68 & 35.76 & 26.43 \\
Ttn53 & 29 Oct-25 Nov 1995 & Inter & 3.48 & 13.78 & 2.27 & 17.54 & 1.12 & 18.49 & 35.84 & 26.18 \\
Ttn54 & 30 Nov-26 Dez 1995 & NE - early & 3.36 & 15.91 & 2.57 & 19.98 & 0.69 & 16.25 & 35.85 & 26.48 \\
Ttn43 & 8 Jan-11 Feb 1995 & NE - peak & 3.12 & 15.89 & 2.57 & 19.88 & 0.65 & 15.66 & 35.82 & 26.48 \\
Ttn45 & 14 Mar-08 Apr 1995 & NE - late & 3.25 & 15.08 & 2.53 & 20.23 & 0.76 & 16.44 & 35.81 & 26.30 \\
\hline WEST & & & & & & & & & & \\
Ttn49 & 18 Jul-13 Aug 1995 & SW - early & 0.00 & 8.57 & 2.40 & 25.68 & 3.49 & 15.34 & 35.81 & 26.55 \\
Ttn50 & 14 Aug-13 Sep 1995 & SW - late & 0.01 & 7.74 & 2.40 & 25.56 & 8.57 & 15.12 & 35.74 & 26.55 \\
M74 & 18 Sep-4 Oct 2007 & SW - late & 0.04 & 10.06 & 2.36 & 23.25 & 2.07 & 15.95 & 36.00 & 26.57 \\
Ttn53 & 29 Oct-25 Nov 1995 & Inter & 0.03 & 10.23 & 2.47 & 24.90 & 1.41 & 15.55 & 35.84 & 26.53 \\
Ttn54 & 30 Nov-26 Dez 1995 & NE - early & 0.01 & 10.00 & 2.44 & 24.64 & 3.26 & 15.97 & 35.94 & 26.51 \\
Ttn43 & 8 Jan-11 Feb 1995 & NE - peak & 0.01 & 7.36 & 2.39 & 26.88 & 9.84 & 15.26 & 35.76 & 26.53 \\
Ttn45 & 14 Mar-8 Apr 1995 & NE - late & 0.07 & 9.51 & 2.43 & 25.13 & 4.71 & 15.79 & 35.87 & 26.49 \\
\hline
\end{tabular}

separated from the area of active denitrification on the shelf due the inflow of the West India Undercurrent (WIUC) carrying slightly oxygen-enriched waters of equatorial origin northwards during the SW monsoon (Naqvi et al., 2006). Since the high denitrification rates were furthermore measured at water depths between 20 and $80 \mathrm{~m}$, it is assumed that $\mathrm{NO}_{3}^{-}$loss on the Indian shelf hardly affect the SNM, which is at water depths between 125 and $375 \mathrm{~m}$ in the open ocean.

$\mathrm{N}$ losses measured by means of incubation experiments off Pakistan in surface sediment at water depth of $360 \mathrm{~m}$ revealed denitrification and anammox rates of 2.7 and $0.21 \mathrm{mmol} \mathrm{N} \mathrm{m}^{-2} \mathrm{day}^{-1}$, respectively (Sokoll et al., 2012). This is within the range of those measured by Schwartz et al. (2009) at the Pakistan continental margin $\left(0.07-3.78 \mathrm{mmol} \mathrm{N} \mathrm{m}^{-2} \mathrm{day}^{-1}\right)$ and exceeds those measured on the Indian shelf of $0.17-1.33 \mathrm{mmol} \mathrm{N} \mathrm{m}^{-2}$ day $^{-1}$ (Naik, 2006; Schwartz et al., 2009). According to the ETOPO01 model, the area with water depths between 125 and $375 \mathrm{~m}$ along the Indian continental margin amounts to $2.2 \times 10^{10} \mathrm{~m}^{2}$. The volume of water above that area and below a water depth of $125 \mathrm{~m}$ was estimated to be $1.84 \times 10^{12} \mathrm{~m}^{3}$. Assuming the same $\mathrm{NO}_{3}^{-}$loss rates within the depth range as off Pakistan at a water depth of $360 \mathrm{~m}$ suggests a sedimentary $\mathrm{NO}_{3}^{-}$loss rate of $0.33 \mathrm{Tg} \mathrm{N} \mathrm{yr}^{-1}$ $\left(\left[2.7+0.21 \mathrm{mmol} \mathrm{N} \mathrm{m}^{-2} \mathrm{day}^{-1}\right] \times 2.2 \times 10^{10} \mathrm{~m}^{2} \times\right.$

$365 \times 14.01)$. Furthermore, considering denitrification rates in the overlying water column as on the shelf results in a $\mathrm{NO}_{3}^{-}$loss of $0.5 \mathrm{Tg} \mathrm{N} \mathrm{yr}^{-1}$ $\left(1.84 \times 10^{12} \times 365 \times 14.01 \mathrm{~m}^{3} \times 52.7 \mathrm{nmol} \mathrm{NL}^{-1}\right.$ day $\left.^{-1}\right)$. The resulting total $\mathrm{NO}_{3}^{-}$loss in the water column and sediments of $0.83 \mathrm{Tg} \mathrm{Nyr}^{-1}$ on the Pakistan margin thus represents only $5 \%$ of the estimated $\mathrm{NO}_{3}^{-}$loss of $15.36 \mathrm{Tg}$ $\mathrm{N} \mathrm{yr}^{-1}$ within the SNM. This indicates that boundary processes along continental margin are of minor importance for the $\mathrm{NO}_{3}^{-}$deficits in the Arabian Sea and cannot significantly impact the SNM.

\subsection{Interaction between the SNM in the central and eastern Arabian Sea and the upwelling region in the western Arabian Sea}

Mixing in the ocean's interior occurs along isopycnal surfaces and likely varies seasonally between the western Arabian Sea upwelling area and the eastern SNM. We averaged all seawater properties in the western Arabian Sea within the density range (sigma-t: 26.3-26.6) in which the SNM was located in the eastern Arabian Sea (Table 1). The mean oxygen concentrations in the western Arabian Sea showed highest values during the peak of the NE monsoon in January/February (Fig. 5d). At this time, winter convection driven by wintertime cooling of sea surface deepens the mixed layer. Since the depth of the mixed layer exceeds the depth of the euphotic zone, light limitation reduces photosynthesis and the resulting export of organic carbon in January/February (Fig. 5d; Rixen et al., 2005). Reduced organic carbon export fluxes and increased ventilation due to deep mixing could explain the high mid-water oxygen concentrations and the interrupted westward expansion of the SNM during the peak NE monsoon in 1995 (Fig. 4, cruise ttn43). 

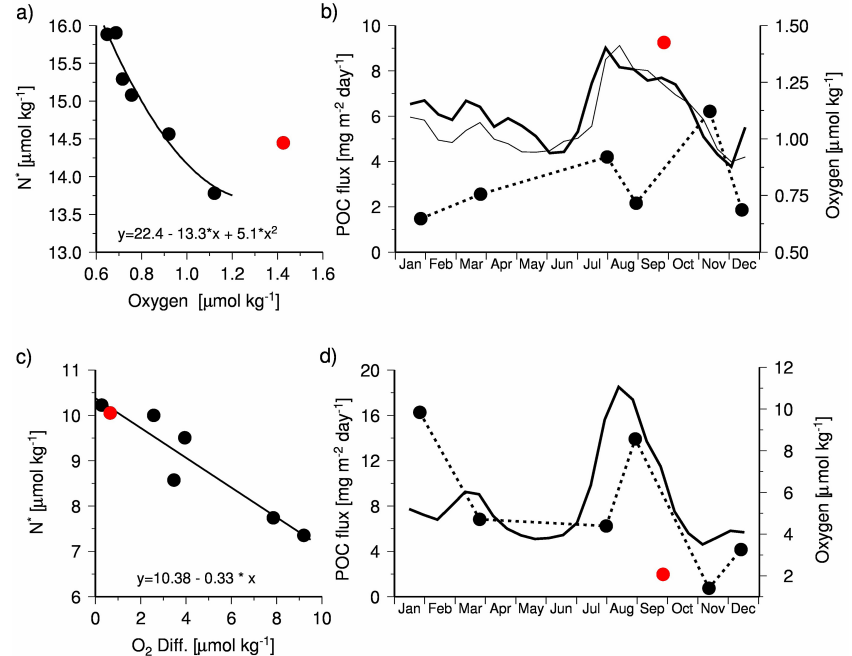

Figure 5. $\mathrm{NO}_{3}^{-}$deficits expressed as $N^{*}$ versus oxygen concentrations in the SNM (a). Monthly mean organic carbon fluxes measured by sediment traps at a water depth of $3000 \mathrm{~m}$ in the central (bold line) and eastern Arabian Sea (thin line) (Haake et al., 1993; Rixen et al., 2005), as well as the mean oxygen concentrations in the SNM measured during the US JGOFS cruises in 1995 and the cruise M74/1b in 2007 (b). Differences between oxygen concentrations in the SNM and the western Arabian Sea versus $N^{*}$ in the western Arabian Sea (c). Monthly mean organic carbon fluxes measured by sediment traps at a water depth of $3000 \mathrm{~m}$ in the western Arabian Sea (bold line; Haake et al., 1993; Rixen et al., 2005) and the mean oxygen concentrations in the western Arabian Sea measured during the U.S. JGOFS cruises in 1995 and the cruise M74/1b in 2007 (d). Black circles indicate the US JGOFS data and the red circle indicates the one derived from the cruise M74/1b. The oxygen and $N^{*}$ data are given in Table 1 .

In March enhanced fluxes seem to have reduced oxygen concentrations, which remained low until the SW monsoon (Fig. 5d). At the same time as the peak in organic carbon flux at the end of the SW monsoon in September, the oxygen concentrations reached their second maximum (Fig. 5d). In line with model studies (Anderson et al., 2007), this implies that, despite high organic carbon fluxes, a reinforced propagation of oxygen-enriched ICW through the Strait of Socotra into the region off southeastern Oman increased the oxygen concentration in the western Arabian Sea and inhibited the westward expansion of SNM during the SW monsoon (Fig. 4).

"Oxygen-enriched" is a relative term in this context. In mass balance calculations, the ICW was considered oxygenpoor and its preformed oxygen depletion is a crucial factor for maintaining the OMZ in the Arabian Sea (Pichevin et al., 2007; Rixen and Ittekkot, 2005; Sen Gupta et al., 1975; Warren, 1994). According to the World Ocean Atlas 2009 (Garcia et al., 2010), the water masses in the Strait of Socotra are undersaturated with respect to oxygen and have concentrations of approximately $52 \mu \mathrm{mol} \mathrm{O} \mathrm{Ogg}^{-1}$ (averaged between 10 and $11^{\circ} \mathrm{N}$ and 51 and $53^{\circ} \mathrm{E}$ and at a water depth between 200 and $400 \mathrm{~m}$ ). Compared to the western Arabian Sea off the southeastern coast of Oman, where the oxygen concentrations were $<10 \mu \mathrm{mol} \mathrm{O} \mathrm{kg}^{-1}$, the ICW is oxygenenriched. Since the ICW was probably oxygen-saturated during its formation in the southern Indian Ocean and lost oxygen on its way through the Indian Ocean, it is considered oxygen-depleted with respect to its potential ventilation impacts resulting from its original oxygen concentrations. However, as long as oxygen concentrations of ICW in the Strait of Socotra are higher than those in the Arabian Sea, its inflow increases the oxygen concentrations in the Arabian Sea, and therefore the ICW is considered oxygen-enriched in the following discussion.

During the peak of the NE and the SW monsoons when oxygen concentrations in the western Arabian Sea reached their maxima, oxygen concentrations in the SNM were extremely low (Fig. 5b, d). The difference between the oxygen concentrations in the west and the SNM was highest during these two phases. Conversely, the lowest difference in the oxygen concentrations occurred during the intermonsoon, suggesting that, in the absence of high organic carbon export fluxes and inputs of ICW, isopycnal mixing reduced the gradient between these two regions (Fig. 5b, d). The lower gradient of oxygen concentrations between these two regions was associated with higher $\mathrm{NO}_{3}^{-}$deficits in the western Arabian Sea (Fig. 5c), suggesting that denitrification signals from the SNM propagate by isopycnal mixing into the upwelling region.

\subsection{Interannual variability}

In order to investigate changes between the SW monsoon 1995 and that in 2007, 10 JGOFS sites were revisited during a research cruise with RV Meteor (M74/1b; Figs. 1, 3). During sampling off Oman in September 2007, upwelling was still active, as indicated by enhanced phosphate $\left(>1 \mu \mathrm{mol} \mathrm{kg}{ }^{-1}\right)$ and chlorophyll concentrations in surface waters (Fig. 6).

The spatial expansion of the denitrifying zone was much larger during the late SW monsoon in 2007 than during a similar period in 1995 (Fig. 7). The denitrifying zone revealed a pronounced westward expansion with a weak SNM at station 949/S6, where no SNM was observed during the late SW monsoon in 1995 (Fig. 8b, d). Furthermore, enhanced $N^{*}$ values associated with the SNM support the occurrence of denitrification in 2007 (Fig. 8a, b). The mean $\mathrm{NO}_{2}^{-}$concentrations in the SNM were higher in 2007 than observed at any time in 1995 (Figs. 7, 8c, Table 1). In line with the linear correlation between denitrification rates and $\mathrm{NO}_{2}^{-}$concentrations (Bulow et al., 2010), this implies that denitrification rates were on average higher in 2007 than in 1995.

Despite higher denitrification rates as indicated by the higher $\mathrm{NO}_{2}^{-}$concentrations, the $\mathrm{NO}_{3}^{-}$deficit was lower and the oxygen concentrations were higher during the SW monsoon in 2007 than in 1995 (Table 1, Figs. 5a, b, 8a). Unlike 

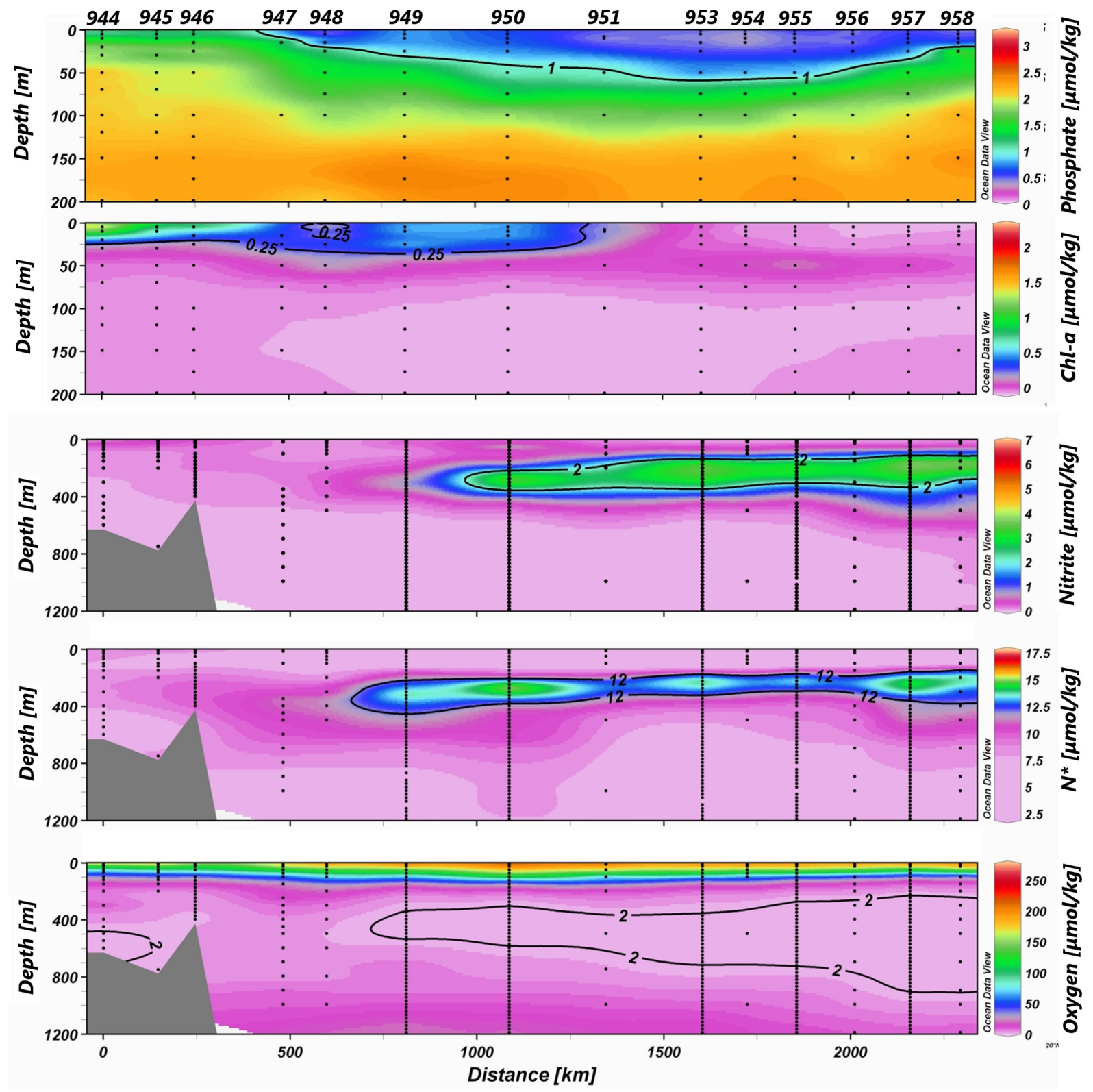

Figure 6. Transects from the western (944) towards the central (950) and eastern Arabian Sea (951-958) obtained during the RV Meteor cruise M74/1b in 2007 (see Table 1). The transect is given in Fig. $3 b$.

$\mathrm{NO}_{2}^{-}$, which is constantly formed and consumed, the $\mathrm{NO}_{3}^{-}$ deficit is an accumulative water mass tracer which is strongly influenced by the residence time of water in the SNM. This holds true also for oxygen as long as air-sea fluxes and vertical mixing do not influence it. Accordingly, a stronger SW monsoon could have enhanced denitrification rates by increasing upwelling-driven organic carbon exports into the SNM while the stronger inflow of ICW reduced the residence time of water within the SNM and thus the concentrations of oxygen and nitrate as seen in 2007 compared to 1995 (Fig. 5b). Associated accelerated mixing could, on the other hand, also explain the westward expansion of the
SNM (Fig. 7), the enhanced $N^{*}$ value, and the decreased oxygen concentrations in the upwelling region as seen in 2007 (Fig. 5c, d). The low oxygen concentration might have also favoured the high anammox rates measured by Jensen et al. (2011) during September 2007 on the continental margin off Oman, which in turn might have limited westward expansion of the SNM. But was the SW monsoon in 2007 stronger than the one in 1995?

Sea surface temperatures (SSTs) were used as an indicator of upwelling strength (Rixen et al., 1996). However, its use is problematic since the impact of global warming, through mixing and deep water formation, penetrates into the 

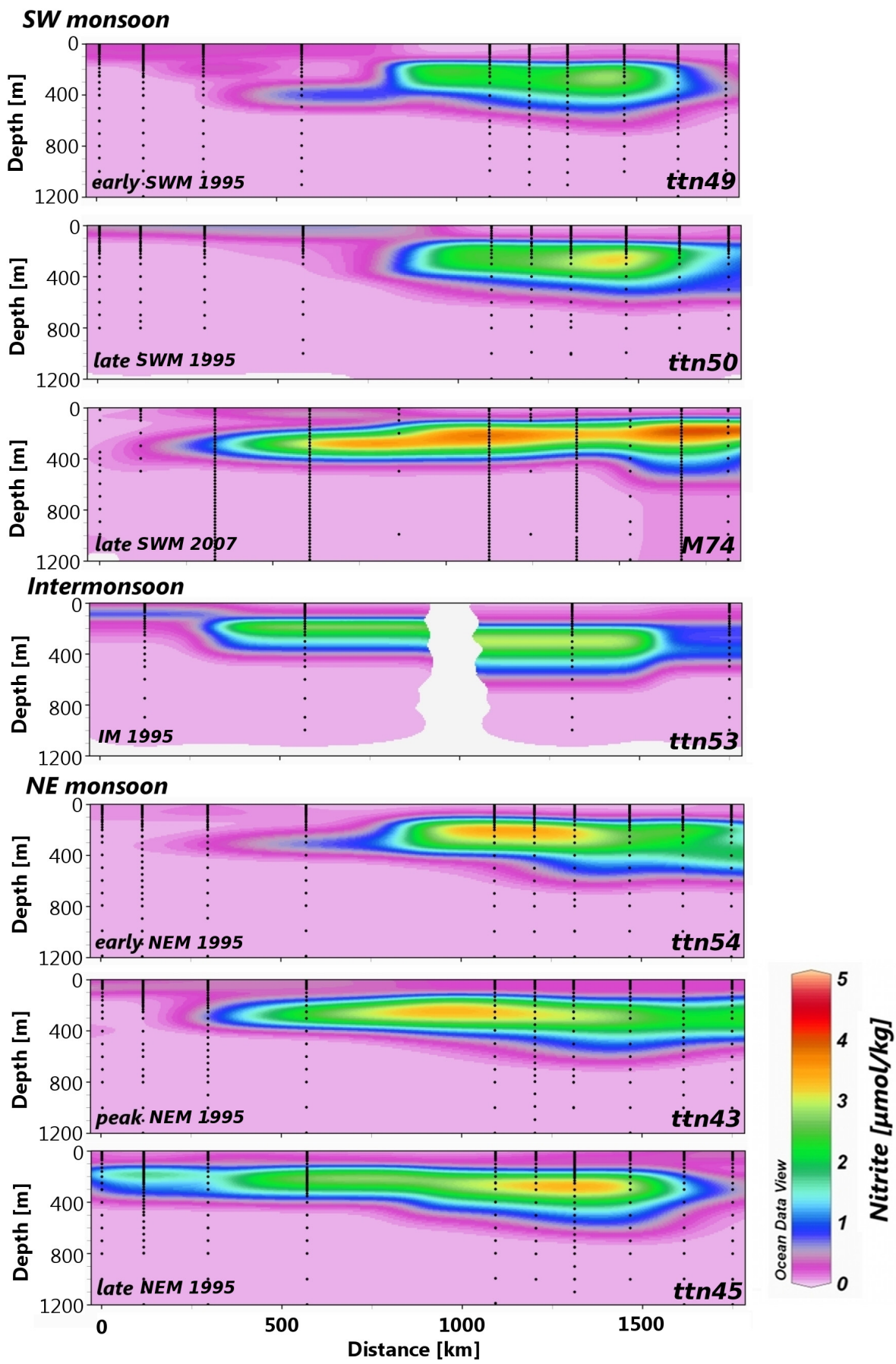

Figure 7. Cross sections showing the seasonal distribution of nitrite during the US JGOFS cruises in 1995 and the late SW monsoon 2007 (see Fig. 1 and Table 1). The transects are given in Fig. $3 \mathrm{c}$ and d.

ocean's interior and warms the subsurface water that upwells along the coasts (Levitus et al., 2000). In order to reduce this global-warming-induced problem, we decided to calculate the cooling caused by upwelling as the SST difference between the spring intermonsoon and the following SW monsoon (Fig. 9). Satellite-derived records of SST from 1982 to 2007 (Smith et al., 2008) were averaged for the upwelling- influenced western Arabian Sea between 13 and $23^{\circ} \mathrm{N}$ and 55 and $65^{\circ}$ E. For each year of the resulting time series, the mean intermonsoon and SW monsoon SSTs were calculated by averaging the SSTs between April and May as well as June and September. Between 1982 and 2007, the SSTs were on average $1.82^{\circ} \mathrm{C}$ lower during the SW monsoon than during the spring intermonsoon. The decade between 1997 and 

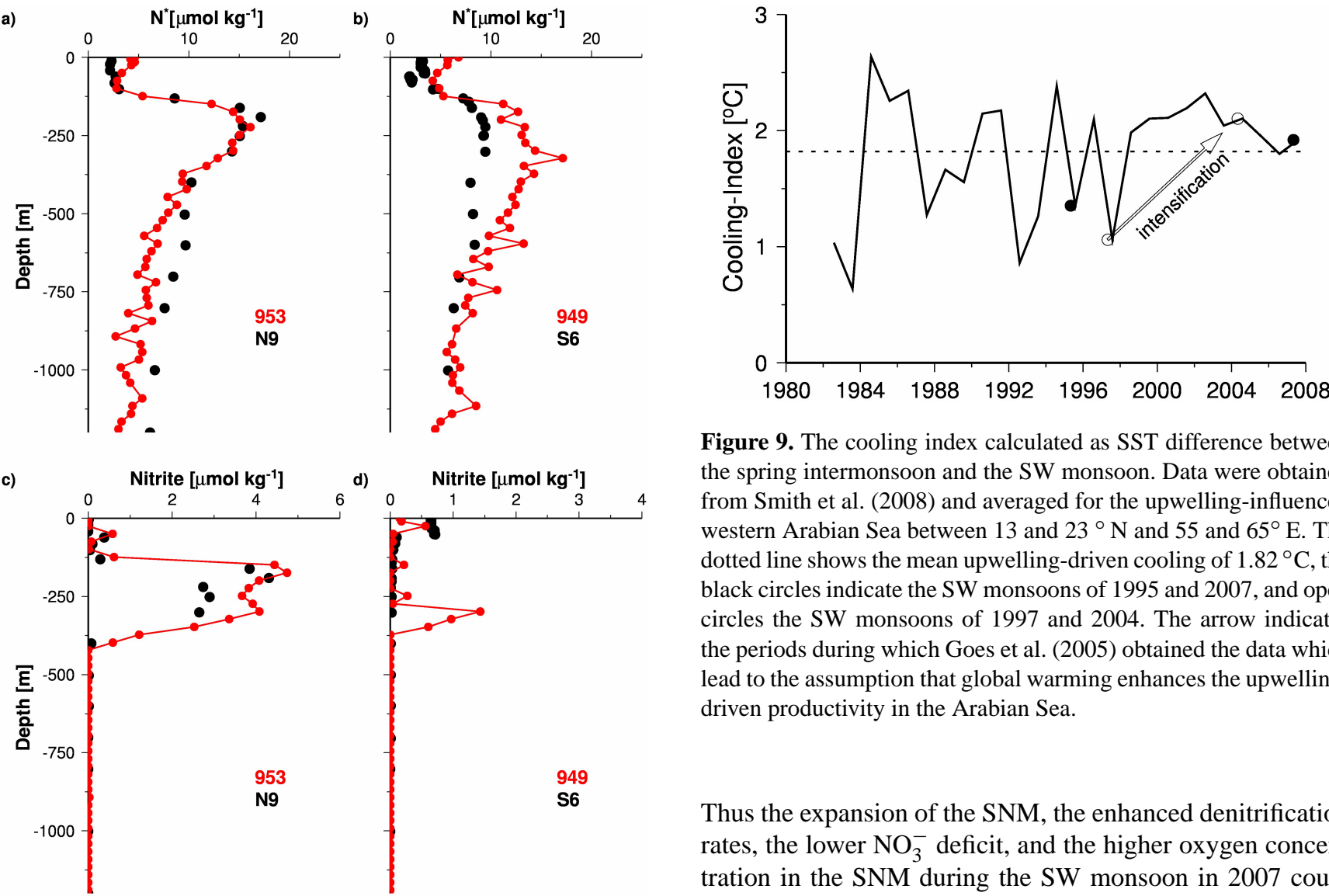

Figure 9. The cooling index calculated as SST difference between the spring intermonsoon and the SW monsoon. Data were obtained from Smith et al. (2008) and averaged for the upwelling-influenced western Arabian Sea between 13 and $23^{\circ} \mathrm{N}$ and 55 and $65^{\circ} \mathrm{E}$. The dotted line shows the mean upwelling-driven cooling of $1.82^{\circ} \mathrm{C}$, the black circles indicate the SW monsoons of 1995 and 2007, and open circles the SW monsoons of 1997 and 2004. The arrow indicates the periods during which Goes et al. (2005) obtained the data which lead to the assumption that global warming enhances the upwellingdriven productivity in the Arabian Sea.

Thus the expansion of the SNM, the enhanced denitrification rates, the lower $\mathrm{NO}_{3}^{-}$deficit, and the higher oxygen concentration in the SNM during the SW monsoon in 2007 could have been a cumulative effect of a series of stronger monsoons occurring after 1995.

(c, d) obtained during the JGOFS late SW monsoon 1995 cruise ttn50 in the eastern (N9) and central (S6) Arabian Sea (black circles) and the M74/1b cruise at the same stations (red circles, stations 953 and 949).

2007 was in general characterized by SW monsoons with an upwelling-induced cooling above this average (Fig. 9).

Between 1997 and 2004, decreasing SSTs and increasing chlorophyll concentrations off Somalia were linked to the shrinking Eurasian snow cover, and it was suggested that global warming started to increase the monsoon-driven upwelling (Goes et al., 2005). In the western Arabian Sea off Oman, chlorophyll concentrations did not reveal such a clear trend but were enhanced during the SW monsoons between 1998 and 2005 compared to those determined during the SW monsoons from 2006 to 2009 (Naqvi et al., 2010). However, according to the cooling indicator, the SW monsoon of 2007 seemed to be part of a series of monsoons which were stronger than the one in 1995 (Fig. 9).

\subsection{Holocene records}

As discussed above, $\delta^{15} \mathrm{~N}$ of $\mathrm{NO}_{3}^{-}$is a useful tracer of denitrification (Fig. 2). Since phytoplankton utilizes $\mathrm{NO}_{3}^{-}$and forms organic matter that is exported into the deep sea, the $\delta^{15} \mathrm{~N}$ signatures preserved in sediments can be used as indicators of past changes in denitrification rates in the Arabian Sea (Altabet et al., 1999, 2002; Suthhof et al., 2001). The only Holocene sedimentary records of $\delta^{15} \mathrm{~N}$ that are almost complete are from the upwelling region off Oman (RC2723; Altabet et al., 2002) and from the Makran coast (Pakistan) close to the SNM (MD-04 2876; Pichevin et al., 2007; Figs. 1, 10). These two cores show increasing $\delta^{15} \mathrm{~N}$ values between 6 and $7 \mathrm{kyr} \mathrm{BP}$ and the present, which were assumed to be caused by increasing denitrification rates. Since sedimentary proxies point towards reduced productivity, the increasing Holocene denitrification was explained by reduced ventilation in conjunction with a reorganization of the ICW and the NIHSIW during the Holocene sea level rise (Pichevin et al., 2007). A decreasing productivity is also in line with palaeoclimatic records on moisture conditions derived from central Asian terrestrial archives, indicating a weakening of the monsoon from the middle to late Holocene (Fig. 10b; Herzschuh, 2006). The Holocene weakening of the monsoon 

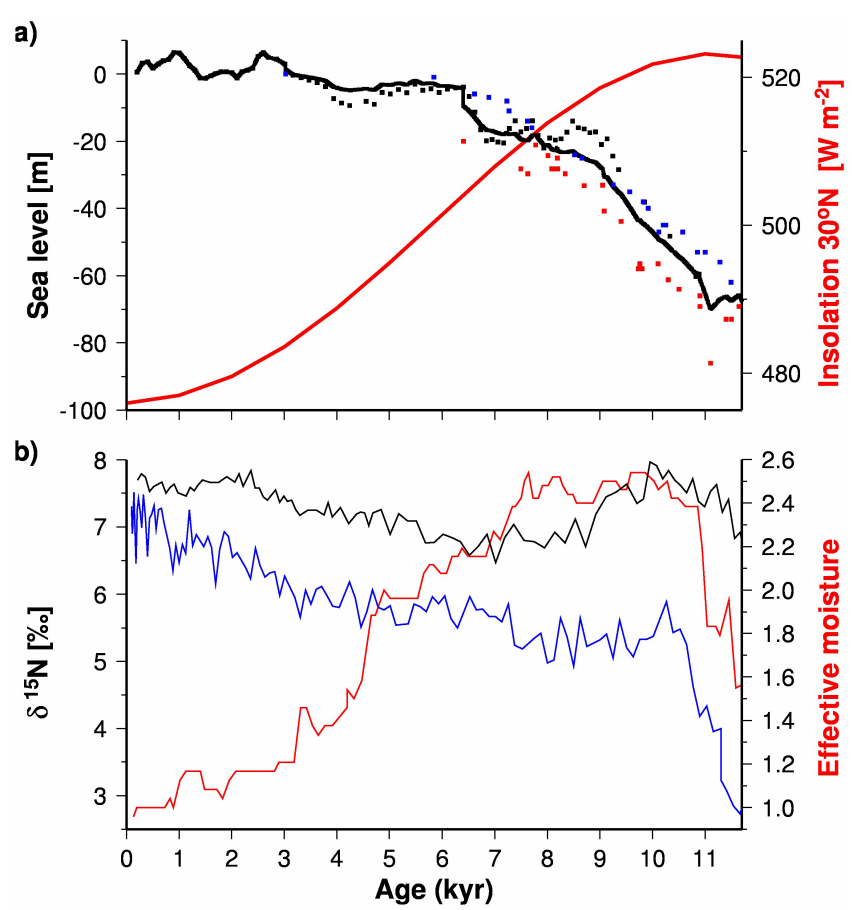

Figure 10. (a) Holocene sea level changes obtained from Sidall et al. (2003, black squares), Fairbanks (1989, blue squares), Bard et al. (2000, red squares), and Arz et al. (2007, red squares). The black line is the mean calculated from all data points. The blue curve shows the solar insolation at $30^{\circ} \mathrm{N}$ obtained from Berger and Loutre (1991). (b) The red curve reveals the central Asian effective moisture index, representing monsoon strength (Herzschuh, 2006). The black line shows the $\delta^{15} \mathrm{~N}$ record from the core RC27-23 (Altabet et al., 2002) and the blue curve reveals the $\delta^{15} \mathrm{~N}$ records from the core MD-04 2876 (Pichevin et al., 2007).

follows the decreasing solar insolation at $30^{\circ} \mathrm{N}$. The insolation changes were driven by variations in Earth's orbital parameters (Berger and Loutre, 1991), which were assumed to be the main factors controlling monsoon strength (Kutzbach, 1981; Ruddiman, 2006). However, the current sea level was reached at about $6 \mathrm{kyr} \mathrm{BP}$ (Arz et al., 2007; Bard et al., 1990; Fairbanks, 1989; Siddall et al., 2003) and the $\delta^{15} \mathrm{~N}$ values continued to rise thereafter (Fig. 10). Based on our results, we suggest that the enhanced accumulation of denitrification signals reflect an increasing mid-water residence time caused by the weakening of the monsoon and the reduced inflow of ICW.

A further consequence of weaker monsoons should be reduced isopycnal mixing and thus a larger gradient of denitrification signals between the upwelling region in the western Arabian Sea and the eastern SNM. However, a direct comparison of $\delta^{15} \mathrm{~N}$ data obtained from the coast of Oman and Pakistan is difficult for several reasons. First of all, the water depth from which supplied nutrients originate differs between the upwelling and the non-upwelling regions off Oman and Pakistan. Whereas thermohaline or wind-induced mixed-layer deepening may entrain nutrients from $\leq 100 \mathrm{~m}$ depth (Rao et al., 1989) with $\delta^{15} \mathrm{~N}_{\mathrm{NO}_{3}}$ values around $9 \%$, upwelling water originates at water depths of approximately $300 \mathrm{~m}$ with $\delta^{15} \mathrm{~N}_{\mathrm{NO}_{3}}$ values $\geq 14 \%$ o (see Fig. 2; Brock et al., 1992; Rixen et al., 2000). Moreover, isotopic fractionation during nutrient uptake and during the decomposition of organic matter in surface sediments influence the sedimentary $\delta^{15} \mathrm{~N}$ signals and require careful evaluation when different archives are compared (Gaye-Haake et al., 2005).

\section{Conclusions}

Based on the JGOFS data from 1995, the area of the SNM characterized by $\mathrm{NO}_{2}^{-}$concentrations $>2 \mu \mathrm{mol} \mathrm{kg}{ }^{-1}$ was $63 \%$ larger than a similarly determined estimate based on all pre-JGOFS data. However, the database is still too small in order to be able distinguish between trends and the pronounced seasonal and interannual variability of the spatial expansion of the core of the denitrifying zone. Seasonal variations mainly followed the monsoon-driven seasonal reversal of the current regime. During the NE monsoon, the SNM expanded westward as a result of the reversal of the current regime. During the SW monsoon the SNM retreated eastward due to the inflow of oxygen-enriched ICW.

On an interannual timescale, a stronger SW monsoon enhanced denitrification rates by increasing organic carbon export production. The associated enhanced $\mathrm{NO}_{3}^{-}$losses could be compensated for by the increased inflow of ICW and the resulting enhanced $\mathrm{NO}_{3}^{-}$supply, which in turn could have sustained enhanced organic carbon export production. Furthermore, the stronger inflow of ICW lowered the accumulation of denitrification tracers by reducing the residence time of water in the SNM. This finding is supported by palaeoclimatic studies showing that the enhanced preservation of accumulative denitrification tracers in marine sediments of the Arabian Sea was accompanied by a weakening of the monsoon during the Holocene (and vice versa).

Acknowledgements. We thank M. Birkicht for his help on board RV Meteor and Udo Hübner for operating the CTD and rosette sampler and processing the CTD data. The excellent support by the captain and crew of Meteor 74/1b and the financial support from DFG grant RI 1194/3-1 and GA 755/4-1 are gratefully acknowledged. P. Wessels, W. H. F. Smith and Rainer Schlitzer are acknowledged for providing the Generic Mapping Tools (GMT) and Ocean Data View.

Edited by: S. W. A. Naqvi 


\section{References}

Altabet, M. A., Higginson, M. J., and Murray, D. W.: The effect of millennial-scale changes in Arabian Sea denitrification on atmospheric $\mathrm{CO}_{2}$, Nature, 415, 159-162, 2002.

Amante, C. and Eakins, B. W.: ETOPO1-1 Arc-minute global relief model: procedures, data sources and analysis, NOAA, National Geophysical Data Center, Mar. Geol. Geophys. Div., Boulder, Colorado, 19 pp., 2009.

Anderson, T. R., Ryabchenko, V. A., Fasham, M. J. R., and Gorchakov, V. A.: Denitrification in the Arabian Sea: A 3-D ecosystem modelling study, Deep-Sea Res. Pt. I, 54, 2082-2119, 2007.

Arz, H. W., Lamy, F., Ganopolski, A., Nowaczyk, N., and Pätzold, J.: Dominant Northern Hemisphere climate control over millennial-scale glacial sea-level variability, Quat. Sci. Rev., 26, 312-321, 2007.

Bange, H. W., Rixen, T., Johansen, A. M., Siefert, R. L., Ramesh, R., Ittekkot, V., Hoffmann, M. R., and Andreae, M. O.: A revised nitrogen budget for the Arabian Sea, Global Biogeochem. Cy., 14, 1283-1297, 2000.

Bard, E., Hamelin, B., Arnold, M., Montaggioni, L., Cabioch, G., Faure, G., and Rougerie, F.: Deglacial sea-level record from Tahiti corals and the timing of global meltwater discharge, Nature, 382, 241-244, 1996.

Bendschneider, K. and Robinson, R. J.: A new spectrophotometric determination of nitrite in seawater, J. Mar. Res., 2, 87-96, 1952.

Berger, A. and Loutre, M. F.: Insolation values for the climate of the last 10 million years, Quat. Sci. Rev., 10, 297-317, 1991.

Böhlke, J. K., Mroczkowski, S. J., and Coplen, T. B.: Oxygen isotopes in nitrate: new reference materials for 180:170:16O measurements and observations on nitrate-water equilibration, Rapid Commun. Mass Spectrom., 17, 1835-1846, 2003.

Brandes, J. A. and Devol, A. H.: A global marine-fixed nitrogen isotopic budget: Implications for Holocene nitrogen cycling, Global Biogeochem. Cy., 16, 67-61-67-14, 2002.

Brock, J. C., McClain, C. R., Luther, M. E., and Hay, W. W.: The Phytplankton Bloom in the Northwestern Arabian Sea During the Southwest Monsoon of 1979, J. Geophys. Res., 96, 20623620642, 1991.

Brock, J. C., McClain, C. R., and Hay, W. W.: A Southwest Monsoon Hydrographic Climatology for the Northwestern Arabian Sea, J. Geophys. Res., 97, 9455-9465, 1992.

Bulow, S. E., Rich, J. J., Naik, H. S., Pratihary, A. K., and Ward, B. B.: Denitrification exceeds anammox as a nitrogen loss pathway in the Arabian Sea oxygen minimum zone, Deep-Sea Res. Pt. I, 57, 384-393, 2010.

Casciotti, K. L. and McIlvin, M. R.: Isotopic analyses of nitrate and nitrite from reference mixtures and application to Eastern Tropical North Pacific waters, Mar. Chem., 107, 184-201, 2007.

Cline, J. D. and Kaplan, I. R.: Isotopic fractionation of dissolved nitrate during denitrification in the eastern tropical north pacific ocean, Mar. Chem., 3, 271-299, 1975.

Codispoti, L. A.: An oceanic fixed nitrogen sink exceeding $400 \mathrm{Tg} \mathrm{N} \mathrm{a}^{-1}$ vs the concept of homeostasis in the fixed-nitrogen inventory, Biogeosciences, 4, 233-253, doi:10.5194/bg-4-2332007, 2007.

Codispoti, L. A., Brandes, J. A., Christensen, J. P., Devol, A. H., Naqvi, S. W. A., Paerl, H. W., and Yoshinari, T.: The oceanic fixed nitrogen and nitrous oxide budgets: Moving targets as we enter the anthropocene?, Sci. Mar., 65, 85-105, 2001a.
Codispoti, L. A., Brandes, J. A., Christensen, J. P., Devol, A. H., Naqvi, S. W. A., Paerl, H. W., and Yoshinari, T.: The oceanic fixed nitrogen and nitrous oxide budgets: Moving targets as we enter the anthropocene?, Sci. Mar., 65, 85-105, 2001 b.

Deuser, W. G., Ross, E. H., and Mlodzinska, Z. J.: Evidence for and rate of denitrification in the Arabian Sea, Deep-Sea Res., 25, 431-445, 1978.

Deutsch, C., Sarmiento, J. L., Sigman, D. M., Gruber, N., and Dunne, J. P.: Spatial coupling of nitrogen inputs and losses in the ocean, Nature, 445, 163-167, 2007.

Devol, A. H., Uhlenhopp, A. G., Naqvi, S. W. A., Brandes, J. A., Jayakumar, D. A., Naik, H., Gaurin, S., Codispoti, L. A., and Yoshinari, T.: Denitrification rates and excess nitrogen gas concentrations in the Arabian Sea oxygen deficient zone, Deep-Sea Res. Pt. I, 53, 1533-1547, 2006.

Dugdale, R. C. and Goering, J. J.: Uptake of new and regenerated forms of nitrogen in primary productivity., Limnol. Oceanogr., 12, 196-206, 1967.

Bard, E., Hamelin, B., Arnold, M., Montaggioni, L., Cabioch, G., Faure, G., and Rougerie, F.: Deglacial sea-level record from Tahiti corals and the timing of global meltwater discharge, Nature, 382, 241-244, 1996.

Findlater, J.: Observational Aspects of the Low-level Crossequatorial Jet Stream of the Western Indian Ocean, Pageoph., 115, 1251-1262, 1977.

Fischer, J., Schott, F., and Stramma, L.: Currents and transports of the Great Whirl-Socotra Gyre system during the summer monsoon, August 1993, J. Geophys. Res., 101, 3573-3587, 1996a.

Fischer, J., Schott, F., and Stramma, L.: Currents and transports of the Great Whirl-Socotra Gyre system during the summer monsoon, August 1993, J. Geophys. Res. Oc., 101, 3573-3587, 1996 b.

Garcia, H. E., Locarnini, R. A., Boyer, T. P., Antonov, J. I., Zweng, M. M., Baranova, O. K., and Johnson, D. R.: World Ocean Atlas 2009, in: NOAA Atlas NESDIS 71, edited by: Levitus, S., US Government Printing Office, Washington, D.C., 398 pp., 2010.

Gaye, B., Nagel, B., Dähnke, K., Rixen, T., and Emeis, K.-C.: Evidence of parallel denitrification and nitrite oxidation in the ODZ of the Arabian Sea from paired stable isotopes of nitrate and nitrite, Global Biogeochem. Cy., 2011, GB004115, doi:10.1002/2011gb004115, 2013.

Gaye-Haake, B., Lahajnar, N., Emeis, K.-C., Unger, D., Rixen, T., Suthhof, A., Ramaswamy, V., Schulz, H., Paropkari, A. L., Guptha, M. V. S., and Ittekkot, V.: Stable nitrogen isotopic ratios of sinking particles and sediments from the northern Indian Ocean, Mar. Chem., 96, 243-255, 2005.

Gilson, H. C.: The nitrogen cycle, 2-81, 1937.

Goes, J. I., Thoppil, P. G., Gomes, H. d. R., and Fasullo, J. T.: Warming of the Eurasian Landmass Is Making the Arabian Sea More Productive, Science, 308, 545-547, 2005.

Grasshoff, K., Kremling, K., and Ehrhardt, M.: Methods of seawater analysis, 3rd Edn., Wiley-VCH, Weinheim, Germany, 1999.

Gruber, N. and Sarmiento, J. L.: Global patterns of marine nitrogen fixation and denitrification, Global Biogeochem. Cy., 11, 235266, 1997.

Haake, B., Ittekkot, V., Rixen, T., Ramaswamy, V., Nair, R. R., and Curry, W. B.: Seasonality and interannual variability of particle fluxes to the deep Arabian Sea, Deep-Sea Res. I, 40, 1323-1344, 1993 
Herzschuh, U.: Palaeo-moisture evolution in monsoonal Central Asia during the last 50000 years, Quat Sci Rev, 25, 163-178, 2006.

Howell, E. A., Doney, S. C., Fine, R. A., and Olson, D. B.: Geochemical estimates of denitrification in the Arabian Sea and the Bay of Bengal during WOCE, Geophys. Res. Lett., 24, 25492552, 1997.

Jensen, M. M., Lam, P., Revsbech, N. P., Nagel, B., Gaye, B., Jetten, M. S. M., and Kuypers, M. M. M.: Intensive nitrogen loss over the Omani Shelf due to anammox coupled with dissimilatory nitrite reduction to ammonium, ISME J., 5, 1660-1670, 2011.

Kutzbach, J. E.: Monsoon Climate of the Early Holocene: Climate Experiment with the Earth's Orbital Parameters for 9000 Years Ago, Science, 214, 59-61, 1981.

Lam, P., Jensen, M. M., Kock, A., Lettmann, K. A., Plancherel, Y., Lavik, G., Bange, H. W., and Kuypers, M. M. M.: Origin and fate of the secondary nitrite maximum in the Arabian Sea, Biogeosciences, 8, 1565-1577, doi:10.5194/bg-8-1565-2011, 2011.

Levitus, S., Antonov, J. I., Boyer, T. P., and Stephens, C.: Warming of the World Ocean, Science, 287, 2225-2229, 2000.

Mariotti, A., Germon, J. C., Hubert, P., Kaiser, P., Letolle, R., Tardieux, A., and Tardieux, P.: Experimental determination of nitrogen kinetic isotope fractionation: Some principles; illustration for the denitrification and nitrification processes, Plant Soil, 62, 413-430, 1981.

McElroy, M. B.: Marine biological controls on atmospheric $\mathrm{CO}_{2}$ and climate, Nature, 302, 328-329, 1983.

Morrison, J. M., Codispoti, L. A., Gaurin, S., Jones, B., Manghanani, V., and Zheng, Z.: Seasonal variation of hydrographic and nutrient fields during the US JGOFS Arabian Sea Process Study, Deep-Sea Res. II, 45, 2053-2101, 1998.

Morrison, J. M., Codispoti, L. A., Smith, S. L., Wishner, K., Flagg, C., Gardner, W. D., Gaurin, S., Naqvi, S. W. A., Manghnani, V., Prosperie, L., and Gundersen, J. S.: The oxygen minimum zone in the Arabian Sea during 1995, Deep-Sea Res. Pt. II, 46, 19031931, 1999.

Naik, H.: Sedimentary nitrogen cycling over the western continental shlef of India, Geophys. Res. Abstract, 8, 2006.

Naqvi, S. W. A.: Some aspects of the oxygen-deficient conditions and denitrification in the Arabian Sea, J. Mar. Res., 49, 10491072, 1987.

Naqvi, S. W. A. and Shailaja, M. S.: Activity of the respiratory electron transport system and respiration rates within the oxygen minimum layer of the Arabian Sea, Deep-Sea Res. II, 40, 687-695, 1993.

Naqvi, S. W. A., Noronha, R. J., and Reddy, C. V. G.: Denitrification in the Arabian Sea, Deep-Sea Res., 29, 459-469, 1982.

Naqvi, S. W. A., Yoshinari, T., Jayakumar, A., Altabet, M. A., Narvekar, P. V., Devol, A. H., Brandes, J. A., and Codispoti, L. A.: Budgetary and biogeochemical implications of $\mathrm{N}_{2} \mathrm{O}$ isotope signatures in the Arabian Sea, Nature, 394, 462-464, 1998.

Naqvi, S. W. A., Jayakumar, D. A., Narvekar, P. V., Naik, H., Sarma, V. V. S. S., D’Souza, W., Joseph, S., and George, M. D.: Increased marine production of $\mathrm{N}_{2} \mathrm{O}$ due to intensifying anoxia on the Indian continental shelf, Nature, 408, 346-349, 2000.

Naqvi, S. W. A., Naik, H., Pratihary, A., D’Souza, W., Narvekar, P. V., Jayakumar, D. A., Devol, A. H., Yoshinari, T., and Saino, T.: Coastal versus open-ocean denitrification in the Arabian Sea, Biogeosciences, 3, 621-633, doi:10.5194/bg-3-621-2006, 2006.
Naqvi, S. W. A., Moffett, J. W., Gauns, M. U., Narvekar, P. V., Pratihary, A. K., Naik, H., Shenoy, D. M., Jayakumar, D. A., Goepfert, T. J., Patra, P. K., Al-Azri, A., and Ahmed, S. I.: The Arabian Sea as a high-nutrient, low-chlorophyll region during the late Southwest Monsoon, Biogeosciences, 7, 2091-2100, doi:10.5194/bg7-2091-2010, 2010.

Naqvi, W. A.: Geographical extent of denitrification in the Arabian Sea in relation to some physical processes, Oceanol. Acta, 14, 281-290, 1991.

Nicholls, J. C., Davies, C. A., and Trimmer, M.: High-resolution profiles and nitrogen isotope tracing reveal a dominant source of nitrous oxide and multiple pathways of nitrogen gas formation in the central Arabian Sea, Limnol. Oceanogr., 52, 156-168, 2007.

Olson, D. B., Hitchcock, G. L., Fine, R. A., and Warren, B. A.: Maintenance of the low-oxygen layer in the central Arabian Sea, Deep-Sea Res. II, 40, 673-685, 1993.

Pichevin, L., Bard, E., Martinez, P., and Billy, I.: Evidence of ventilation changes in the Arabian Sea during the late Quaternary: Implication for denitrification and nitrous oxide emission, Global Biogeochem. Cy., 21, GB4008, doi:10.1029/2006gb002852, 2007.

Ramage, C. S.: Monsoon Climates, in: The Encyclopedia of Climatology, edited by: Oliver, J. E. and Fairbridge, R. W., Van Nostrand Reinhold Company, New York, 1987.

Rao, R. R., Molinari, R. L., and Festa, J. F.: Evolution of the Climatological Near-Surface Thermal Structure of the Tropical Indian Ocean - 1. Description of Mean Monthly Mixed Layer Depth, and Sea Surface Temperature, Surface Current, and Surface Meteorological Fields, J. Geophys. Res., 94, 10801-810815, 1989.

Rixen, T. and Ittekkot, V.: Nitrogen deficits in the Arabian Sea, implications from a three component mixing analysis, Deep-Sea Res. 52, 1879-1891, 2005.

Rixen, T., Haake, B., Ittekkot, V., Guptha, M. V. S., Nair, R. R., and Schlüssel, P.: Coupling between SW monsoon-related surface and deep ocean processes as discerned from continuous particle flux meausurements and correlated satellite data, J. Geophys. Res., 101, 28569-528582, 1996.

Rixen, T., Haake, B., and Ittekkot, V.: Sedimentation in the western Arabian Sea: the role of coastal and open-ocean upwelling, Deep-Sea Res. II, 47, 2155-2178, 2000.

Rixen, T., Guptha, M. V. S., and Ittekkot, V.: Deep ocean fluxes and their link to surface ocean processes and the biological pump, Prog. Oceanogr., 65, 240-259, 2005.

Rixen, T., Ramaswamy, V., Gaye, B., Herunadi, B., Maier-Reimer, E., Bange, H. W., and Ittekkot, V.: Monsoonal and ENSO Impacts on Export Fluxes and the Biological Pump in the Indian Ocean in: Indian Ocean Biogeochemical Processes and Ecological Variability, edited by: Hood, R. R., Wiggert, J. D., Naqvi, S. W. A., Smith , S., and Brink , K., 185, AGU, Washington, 365383, 2009.

Ruddiman, W. F.: What is the timing of orbital-scale monsoon changes?, Quat. Sci. Rev., 25, 657-658, 2006.

Schott, F. and McCreary Jr., J. P.: The monsoon circulation of the Indian Ocean, Prog. Oceanogr., 51, 1-123, 2001.

Schwartz, M. C., Woulds, C., and Cowie, G. L.: Sedimentary denitrification rates across the Arabian Sea oxygen minimum zone, Deep-Sea Res. Pt II, 56, 324-332, 2009. 
Sen Gupta, R. and Naqvi, S. W. A.: Chemical Oceanography of the Indian Ocean, North of the Equator, Deep-Sea Res., 31, 671-706, 1984.

Sen Gupta, R., Fondekar, S. P., Sankaranarayanan, V. N., and de Sousa, S. N.: Chemical Oceanography of the Arabian Sea: Part I - Hydrochemical and Hydrographical Features of the Northern Basin, Indian. J. Mar. Sci., 4, 136-140, 1975.

Siddall, M., Rohling, E. J., Almogi-Labin, A., Hemleben, C., Meischner, D., Schmelzer, I., and Smeed, D. A.: Sea-level fluctuations during the last glacial cycle, Nature, 423, 853-858, 2003.

Sigman, D. M., Casciotti, K. L., Andreani, M., Barford, C., Galanter, M., and Böhlke, J. K.: A Bacterial Method for the Nitrogen Isotopic Analysis of Nitrate in Seawater and Freshwater, Anal. Chem., 73, 4145-4153, 2001.

Smith, T. M., Reynolds, R. W., Peterson, T. C., and Lawrimore, J.: Improvements to NOAA's historival merged land-ocean surface temperature analysis (1880-2006), J. Clim., 21, 2283-2296, 2008.

Sokoll, S., Holtappels, M., Lam, P., Collins, G., Schlüter, M., Lavik, G., and Kuypers, M. M. M.: Benthic nitrogen loss in the Arabian Sea off Pakistan, Front. Microbiol., 3, 1-17, 2012.

Somasundar, K., Rajendran, A., Dileep Kumar, M., and Sen Gupta, R.: Carbon and nitrogen budgets of the Arabian Sea, Mar. Chem., 30, 363-377, 1990.

Stramma, L., Fischer, J., and Schott, F.: The flow field off southwest India at $8 \mathrm{~N}$ during the southwest monsoon of August 1993, J. Mar. Res., 54, 55-72, 1996.
Suthhof, A., Ittekkot, V., and Gaye-Haake, B.: Millenial-scale oscillation of denitrification intensitiy in the Arabian Sea during the late Quaternary and its potential influence on atmospheric $\mathrm{N}_{2} \mathrm{O}$ and global climate, Global Biogeochem. Cy., 15, 637-650, 2001.

Sverdrup, H. U., Johnson, M. W., and Flemming, R. H.: The Oceans, their physics chemistry and general biology, PrenticeHall, Englewood Cliffs, N. J., 1087 pp., 1942.

Ward, B. B., Devol, A. H., Rich, J. J., Chang, B. X., Bulow, S. E., Naik, H., Pratihary, A., and Jayakumar, A.: Denitrification as the dominant nitrogen loss process in the Arabian Sea, Nature, 461, 78-81, 2009.

Warren, B.: Context of the suboxic layer in the Arabian Sea, J. Earth Syst. Sci., 103, 301-314, 1994.

Wiggert, J. D., Jones, B. H., Dickey, T. D., Brink, K. H., Weller, R. A., Marra, J., and Codispoti, L. A.: The Northeast Monsoon's impact on mixing, phytoplankton biomass and nutrient cycling in the Arabian Sea, Deep-Sea Res. Pt. II, 47, 1353-1385, 2000.

Wiggert, J. D., Murtugudde, R. G., and McClain, C. R.: Processes controlling interannual variations in wintertime (Northeast Monsoon) primary productivity in the central Arabian Sea, Deep-Sea Res. Pt. II, 49, 2319-2343, 2002.

You, Y.: Seasonal variations of thermocline circulation and ventilation in the Indian Ocean, J. Geophys. Res., 102, 10391-310422, 1997. 